\title{
The Pope's Agents in CONSTANTINOPLE: EUGENIUS IV'S LEGATION ON THE EVE OF THE COUNCIL OF FERRARA-FLORENCE $(1438-1439)^{*}$
}

\author{
MAARTEN HALFF
}

\begin{abstract}
The legation sent by Pope Eugenius IV to Constantinople in 1437 played a critical role in the long diplomatic efforts towards a reunification of the Latin and Greek Churches, and paved the way for the Council of Ferrara-Florence (1438-1439). With some exceptions, such as the later Cardinal Nicholas Cusanus, the members of the delegation have not received wide attention. This paper presents a biographical analysis of all those involved - the nuncios, the financiers and the galley commanders - and their relationship to the Pope. The findings provide new insight into Eugenius IV's diplomacy towards the Byzantines, as well as Cusanus's place in it. Cusanus's presence added conciliar legitimacy, but the key functions were in the hands of a core team of Venetians - including nonpatricians - who had prior experience in Constantinople and a personal connection to the Pope.
\end{abstract}

\section{Key Words}

Pope Eugenius IV (Gabriele Condulmer), Nicholas of Cusa, Cristoforo Garatone, Marco Condulmer, Antonio Condulmer, Balthasar Lupari, Michele Zono, Council of FerraraFlorence.

* I express my gratitude to Reinhold C. Mueller for inspiring and advising me on archival paths in Venice; they have led me to the distinctly Venetian perspective of this paper. I am grateful to the two anonymous reviewers for their careful reading and thoughtful suggestions. I also thank Peter Bell, Elena Belletti, Christopher Bellitto, Dawn Brancati, Gerald Christianson, Thomas Izbicki, John Monfasani, and Denis Robichaud for comments on an earlier draft, which was presented at the 2019 annual conference of the Renaissance Society of America, in Toronto. 


\section{Papal diplomacy towards the Byzantines on the eve of the Council of Ferrara-Florence}

In a brief biographical sketch written in 1449 , shortly after his appointment as cardinal, the German philosopher and churchman Nicholas of Cusa (1401-1464) stated of himself that:

In his $37^{\text {th }}$ year, he was sent as ambassador by Pope Eugene IV to Constantinople and brought to the Council of Florence the Emperor of the Greeks as well as the Patriarch with 28 archbishops of the Eastern Church who accepted there the faith of the Holy Roman Church. ${ }^{1}$

Cusanus was referring to his mission to Constantinople in 1437, his stay there from September to late November, ${ }^{2}$ and his return on a Venetian convoy ${ }^{3}$

1 Latin text in ERICH MeUthen (ed.), Acta Cusana: Quellen zur Lebensgeschichte des Nikolaus von Kues, [hereinafter AC], vol. I, part 2, Felix Meiner, Hamburg 1983, no. 849. English translation of this segment in Morimichi Watanabe, « Political and Legal Ideas ", in Christopher M. BellitTo, Thomas M. IZBicki, Gerald Christianson (eds.), Nicholas of Cusa. A Guide to a Renaissance Man, Paulist Press, New Jersey 2004, p. 141-165, here p. 147.

2 On Cusanus's time in Constantinople and its impact on him and his work, see, among others: MAARTEN HALFF, « Did Nicholas of Cusa Talk with Muslims? Revisiting Cusanus' Sources for the Cribratio Alkorani and Interfaith Dialogue », Revista Española de Filosofía Medieval, 26/1 (2019), p. 29-58; Walter ANDREAS Euler, « Nikolaus von Kues und die Ostkirche: Idee und Wirklichkeit des Religionsdialog ", in ANDREAS SPEER, PHILIPP STEINKRÜGER (eds.), Knotenpunkt Byzanz: Wissensformen und kulturelle Wechselbeziehungen, De Gruyter, Berlin 2012, (Miscellanea Mediaevalia, 36), p. 496-509; ERICH MeUtHEN, Nicholas of Cusa: A Sketch for a Biography, trans and intr. DAVid CRowner, Gerald Christianson, Catholic University of America Press, Washington, DC, 2010, p. 53-58; Donald F. Duclow, "Life and Works », in Bellitto, Izbicki, Christianson (eds.), Renaissance Man, p. 35; PAULINE M. WATTS, «Renaissance Humanism », in Ibid., p. 174-175; JAMEs E. BIECHLER, «Interreligious Dialogue », in Ibid., p. 272-273; H. LAWRENCE BOND, « Nicholas of Cusa from Constantinople to 'Learned Ignorance': The Historical Matrix for the Formation of the De docta ignorantia », in GERALD CHRISTIANSON, THOMAS M. IZBICKI (eds.), Nicholas of Cusa on Christ and the Church: Essays in Memory of Chandler McCuskey Brooks for the American Cusanus Society, Brill, Leiden 1996 (Studies in the History of Christian Thought, 71), p. 135-163, here p. 138-139.

3 Much has been written about Cusanus's statement, in the dedication of his foundational philosophical work De docta ignorantia (1440), that he arrived at his insights during the sea journey from Constantinople through a « celestial gift from the Father of Lights ». See, among many others, HANS GERHARD SENGER, "'In mari me ex Graecia redeunte, credo superno dono'. Vom Wissensfrust zur gelehrten Unwissenheit. Wie platzte 1437/1438 der Knoten? », in SPEER, STEINKRÜGER, Knotenpunkt Byzanz, p. 481-495; BOND, « The Historical Matrix », p. 136; and MARJoRIE O'Rourke Boyle, "Cusanus at Sea: The Topicality of Illuminative Discourse », The Journal of Religion (1991), p. 180-201. To my knowledge, the possibility has not yet been considered that this illuminative moment may have (also) involved a weather phenomenon: the Byzantine official Sylvester Syropoulos (about whom more below), who travelled on the very same convoy as Cusanus, marveled at seeing, during a violent storm, a « sweet and pleasant brightness which shone down on us then and which some of us saw with our own eyes ", see FotinI KonDYLI, VeRA 
carrying the Byzantine Emperor John VIII Paleologos and the Greek Patriarch Joseph II to what would become the Council of Ferrara-Florence. ${ }^{4}$ At the time of departing on this journey, Cusanus was a member of the Church Council then gathered at Basel - relatively junior in rank, but seen as a rising star and held in high regard for his knowledge of Church history and his legal acumen. The Council had become deeply divided on questions relating to the constitutional powers of the Pope, ${ }^{5}$ and on the issue of where to meet with the Byzantine Emperor and the Greek Orthodox prelates for a reunification of the two Churches. Pope Eugenius IV - the Venetian Gabriele Condulmer - had proposed that it be held in Italy, at a location to be finalized in consultation with the Byzantines upon their arrival to Italy. A minority of the Council, including its most senior members as well as Cusanus, had sided with Eugenius. A numerical majority, in contrast, preferred Basel or Avignon, further away from the Pope's influence.

The differences proved to be irreconcilable and ultimately tore the Council apart. Two opposing Council decrees were adopted on the same day in May 1437,

Andriopoulou, Eirini Panou, Mary B. Cunningham (eds.), sylvester Syropoulos on Politics and Culture in the Fifteenth-Century Mediterranean, Ashgate, Surrey - Burlington 2014 (Birmingham Byzantine and Ottoman studies, 16), p. 201 and fn. 65; the editors suggest that Syropoulos may have seen what is known as the " fire of St. Elmo ».

4 The foundational study on this Council is JosePH GILL, The Council of Florence, Cambridge University Press, Cambridge 1959, to which should now be added SEBASTIAN KoldiTZ, Johannes VIII. Palaiologos und das Konzil von Ferrara-Florenz (1438/39), Hiersemann, Stuttgart 2013 (Monographien zur Geschichte des Mittelalters, 60). Through extensive archival research, Kolditz significantly expands on, and often supersedes, Gill. For the diplomatic preliminaries to the Council - the historical context for the findings presented in this paper - see in particular the discussion in KolditZ, Johannes VIII, p. 42-166. Other relevant studies include: MARIOS PHILIPPIDES, WALTER K. HANAK, Cardinal Isidore, c. 1390-1462. A Late Byzantine Scholar, Warlord and Prelate, Routledge, London-New York 2018, p. 38-78; and GiusePPe Alberigo (ed.), Christian Unity. The Council of Ferrara-Florence 1438/39-1989, Peeters, Leuven 1991 (Bibliotheca ephemeridum theologicarum Lovaniensium, 97). For the Council of Basel, and the confrontation of pro-papal and conciliar factions there, see Michiel Decaluwé, Thomas M. IzBicki, Gerald Christianson (eds.), a Companion to the Council of Basel, Brill, Leiden 2017 (Brill's Companions to the Christian Tradition, 74); MicHIEL DeCALuwÉ, A Successful Defeat. Eugene IV's Struggle with the Council of Basel for Ultimate Authority in the Church, 1431-1449, Belgisch Historisch Instituut te Rome/Institut Historique Belge de Rome, Brussels - Rome 2009 (Bibliothèque de l'Institut historique belge de Rome, 59); JoHANNES Helmrath, Das Basler Konzil 1431-1439. Forschungsstand und Probleme, Böhlau, Cologne 1987 (Kölner historische Abhandlungen, 32); GeRALD Christianson, Cesarini: The Conciliar Cardinal. The Basel Years, 1431-1438, EOS Verlag, St. Ottilien 1979 (Kirchengeschichtliche Quellen und Studien, 10).

5 The literature on what is referred to as conciliarism and the conciliarist movement is extensive. For an assessment, with ample literature citations, see GERALD CHRISTIANSON, « Conciliarism and the Council », in DeCAluwÉ, IzBICKI, Christianson (eds.), Companion to the Council of Basel, p. 75-111.

6 On 7 May 1437. For the texts, see EugEnIo CECCONI, Studi storici sul Concilio di Firenze. Parte prima: Antecedenti del Concilio, Tipografia all'insegna di S. Antonino, Florence 1869, docs. CXX and CXXI. The chronology of events in the period from May to December 1437 is sketched in annex 1 below. Annex 2 provides an overview of the main persons discussed in this paper. 
with each faction claiming to be the legitimate representative of the Council, and each side dispatching embassies to the Byzantines to secure their acceptance. The leaders of the minority faction appointed three delegates - Antonio Martinez de Chaves, the Bishop of Porto; Peter of Versailles, the Bishop of Digne; and Nicholas Cusanus, a provost who clearly enjoyed high standing - to first present their decree to Eugenius. The Pope, residing at the time in Bologna, promptly endorsed the minority decree, and sent the three representatives on to Constantinople along with his own delegation, whom he was dispatching on a specially commissioned Venetian convoy to seal his long negotiations with the Byzantines.

This was a truly formidable diplomatic mission. Eugenius IV (and his predecessor Martin V before him) had sent envoys to Constantinople before, but never at this level and with the ecclesiastical powers of a legation, ${ }^{7}$ and not accompanied by such military strength. Based on earlier agreements with the Byzantines, the legation of 1437 was accompanied by three hundred Cretan crossbowmen to protect the city during the Emperor's absence. They were carried by three great galleys which, on the return journey, would transport hundreds of Byzantine officials to Italy. Eugenius seems to have spared no cost in this endeavour, and to have done so at great political risk: at the time of the convoy's departure from Venice, there was still no certainty as to how the Byzantines would decide in the face of two competing invitations from the West.

Much was at stake for Byzantines, too: the tentative willingness to discuss a unification of the churches was borne out of a desperate need for Western military aid against the advancing Ottomans, ${ }^{8}$ who had virtually surrounded the little that remained of the Byzantine Empire, and who had already launched two sieges against Constantinople, in 1401-1402 and 1422. A crusade against the Ottomans would require joint, coordinated action on the part of the rulers of Latin Christendom. None had the authority or convening power that the Pope wielded, and his ability to persuade European rulers to join in a new crusade in

7 Also noted by Georg HofmanN, «Päpstliche Gesandschaften für den Nahosten, 1418-1453 », Studia Missionalia, 5 (1949), p. 45-71, here p. 59.

8 KoldiTZ, Johannes VIII, p. 69, points out that while the prospect of military aid was a major factor, Emperor John VIII also followed other political considerations, for which see, in detail, Ibid., p. 70-166. Kolditz notes, Ibid., p.130, that the only contemporary Greek source that links Byzantine willingness to discuss unification to their hope for a Western military lifeline is a brief account by an anonymous official, who was on the same convoy to Venice in 1437 as the Emperor and the Patriarch, published and discussed in SOKRATES KugÉAs (ed.), « Notizbuch eines Beamten der Metropolis in Thessalonike aus dem Anfang des XV. Jahrhunderts ", Byzantinische Zeitschrift, 23 (1914/1919), p. 143-163. However, see also the reference, some decades after the events, by the historian THEODORE SPANDOUNES, On the Origin of the Ottoman Emperors, trans. and ed. Donald M. Nicol, Cambridge University Press, Cambridge 1977, p. 28: «The power of the Turk was growing and John realized that he could not resist it on his own ... [John] therefore decided to go to the council [in Italy]». 
support of the Byzantines would, it was understood, be greater once the schism between the two Churches had been healed. ${ }^{9}$ Unification, however, was a highly controversial subject within the Greek church and the population at large, and opinion was deeply divided. ${ }^{10}$ The split in the Latin Church between conciliar and pro-papal forces - including the resulting divisions among secular rulers, reflecting the extent to which they supported either the Council or the Pope ${ }^{11}-$ added a further level of complexity to the negotiations. During the period 14331437, diplomatic preliminaries to a council of union - talks about talks - had taken place on parallel tracks, with both the Council and Eugenius IV sending ambassadors to the Byzantine court and receiving Byzantine representatives. ${ }^{12}$

Following the arrival of Eugenius's legation in Constantinople in September 1437, the papal team's efforts bore fruit: in a major political victory for Eugenius,

9 For the historical context of Western and Byzantine efforts to halt the Ottoman advance see, COLIN IMBER, The Crusade of Varna, 1443-45, Ashgate, Aldershot-Burlington, VT, 2006, in particular the introduction; Kenneth M. Setton, The Papacy and the Levant (1204-1571), vol. II, The Fifteenth Century, The American Philosophical Society, Philadelphia 1978, in particular p. 1-81, covering the years 1402 up to 1444. Briefly: GILL, Council of Florence, p.11-13 and p. 18-19. For contemporary political and intellectual approaches to crusades in the first half of the fifteenth century, see, among others, Margaret Meserve, «Italian Humanists and the Problem of the Crusade ", in Norman Housley (ed.), Crusading in the Fifteenth Century. Message and Impact, Palgrave Macmillan, Hampshire - New York 2004 (Crusades. Subsidia, 8), p. 13-38; and MARK WHELAN, «Dances, Dragons and a Pagan Queen: Sigismund of Luxemburg and the Publicizing of the Ottoman Turkish Threat », in Housley (ed.), The Crusade in the Fifteenth Century, p. 49-63, for a discussion of the role of secular rulers in rallying support for collective action against the Ottoman danger, and Emperor Sigismund's support for the unification of the Greek and Latin Churches in this context. For the Ottoman perspective on the Council and the threat of a united Christian front, see ELIZABETH E. ZACHARIADOU, «The Ottomans, the Greek Orthodox Church and the Perils of the Papacy ", in KondyLi et al., Sylvester Syropoulos, p. 23-32.

10 For Byzantine motivations and attitudes towards unification, see, among others, KolDITZ, Johannes VIII, p. 70-95 (for opinions within the Church) and Ibid., p. 135-166 (for the aristocratic elite); MARIE-HélÈne Blanchet, Georges-Gennadios Scholarios (vers 1400-vers 1472). Un intellectuel orthodoxe face à la disparition de l'Empire byzantin, Editions l'Institute Français d'Études Byzantines, Paris 2008 (Archives de l'Orient chrétien, 20), in particular p. 251-314; Donald M. NicoL, The Last Centuries of Byzantium, 1261-1453, Cambridge University Press, Cambridge 1993 (2 ${ }^{\text {nd }}$ edition), in particular p. 318-368; Deno JoHn GeAnaKoplos, « The Council of Florence (1438-39) and the Problem of Union between the Byzantine and Latin Churches », in ID., Constantinople and the West, The University of Wisconsin Press, Madison, WI, 1989 (Gallica, 25), p. 224-254 (originally printed in Church History, 24 (1955), p. 324-346). For earlier efforts to obtain support in the West by Emperor Manuel II Paleologos, father of John VIII, see JoHN W. BARKER, Manuel II Palaeologus (1391-1425): A Study in Late Byzantine Statesmanship, Rutgers University Press, New Brunswick, NJ, 1969.

11 See Joachim W. Stieber, Pope Eugenius IV, the Council of Basel and the Secular and Ecclesiastical Authorities in the Empire. The Conflict over Supreme Authority and Power in the Church, Brill, Leiden 1978 (Studies in the History of Christian Thought, 13).

12 See, among others, KoldiTz, Johannes VIII, p. 51-63, and, summing up, p. 69; GilL, Council of Florence, p. 46-75. 
the Byzantine Emperor rejected the offer of the Council of Basel majority faction - whose representatives and convoy had arrived in Constantinople shortly after that of Eugenius - and instead decided that the Byzantine delegation would board the papal Venetian galleys and travel to Italy. Arriving in Venice in February 1438, they continued to Ferrara for the opening of the council of union. After lengthy debates, the Council adopted a decree of union on 6 July 1439 which, at least in name, mended the separation of the two churches for a few years ${ }^{13}$ and paved the way for Eugenius to rally the military power of the Latin West for a new crusade in $1444 .^{14}$

Modern studies have assessed and recognized the diplomatic overtures in Constantinople in 1437 as a critical phase in the history of both the Council of Basel and the Council of Ferrara-Florence - and indeed in defining, until today, the relationship between Pope and church council. ${ }^{15}$ But other than the extensive literature about Cusanus, ${ }^{16}$ and references to the nuncio Cristoforo Garatone in studies on the Council of Ferrara-Florence, ${ }^{17}$ very little has been written about the persons who formed part of Eugenius IV's legation or who otherwise contributed to its success: the papal nuncios, the financiers and the galley commanders. Who were they, and what was their relationship to Eugenius and to each other? What experience or value, if any, did they add to the mission? These questions lie at the heart of this paper. By looking at the members of this mission individually and as a group, its aim is to establish a fuller picture of Eugenius's eastern diplomacy, and to reconstruct what he believed could lead to a successful negotiation with the Byzantine court. Equipped with a new, composite portrait of the mission, this paper also proposes a fresh perspective on the activities of Nicholas of Cusa in Constantinople, contributing to a longstanding debate within Cusanus scholarship.

\section{Nicholas of Cusa in Constantinople}

That Cusanus was an important member of the delegation of 1437 and a participant in at least some of the deliberations in Constantinople is beyond doubt. But did he play a lead part as ambassador in bringing back the Byzantine

13 For the Latin text of the decree, see GILL, Council of Florence, p. 412-415; for the aftermath, see Ibid., 305-388, and for reactions and consequences in Constantinople: BLANCHET, Scholarios, p. 315-382.

14 The so-called Crusade of Varna, which ended in defeat of the Christian land forces at that city. See in particular, IMBER, The Crusade of Varna, passim.

15 See the main literature on the respective councils cited above, fn. 4.

16 See above, fn. 2 and 3.

17 See, for example, KoldiTz, Johannes VIII, and GILL, Council of Florence, both ad indicem. 
Emperor and leading members of the Greek Church, as his autobiographical note suggests?

Contemporary sources provide some indications that can help assess Cusanus's own words. Rodrigo Didaci, deacon of Braga and a member of staff of one of the papal envoys, wrote from Constantinople to an associate in Italy that, on one occasion at the Byzantine court, Cusanus had deftly countered some arguments of the Basel majority delegation, drawing on his mastery of council history, and doing so to the satisfaction of the Byzantine Emperor himself. ${ }^{18} \mathrm{~A}$ dispatch by another eyewitness, the Dominican John of Ragusa, who was associated with the majority party of the Council of Basel, contains a possible echo of Cusanus's voice: ${ }^{19}$ Ragusa reported that in the course of one discussion with the Greeks, someone argued that a numerical majority does not always trump the voice of the minority - an allusion to the divisions at the Council of Basel. Ragusa lamented that the Greek Patriarch appeared to have been swayed, among other things, by the argument that the papal faction represented the "sanior pars" of the Council, since it comprised the more senior clerics, including a majority of the cardinals, and was therefore the legitimate representative. ${ }^{20}$ While Ragusa does not attribute these arguments to any named delegate, it may well have been Cusanus who spoke on this particular point, as it has parallels to his thinking. ${ }^{21}$ Furthermore, Francesco Pizolpasso, archbishop of Milan, writing to Cusanus after the events in Constantinople, praised him in general terms for the efforts made for the unification of the Churches, without, however, specifying his exact role. ${ }^{22}$ So did the émigré Greek scholar George of

18 Georg Hofmann, « Rodrigo, Dekan von Braga; Kaiser Johann VIII. Palaiologos. Zwei Briefe aus Konstantinopel, 13. Oktober und 18. November 1437, zur Vorgeschichte des Konzils von Florenz », Orientalia Christiana Periodica, 9 (1943), p. 171-187. Excerpt from Rodrigo's letter in AC, $\mathrm{I} / 2$, no. 329.

19 On John of Ragusa, known as Ivan Stojković in his hometown Ragusa (now Dubrovnik), see further below.

20 Ragusa's report in CECCONI, Studi storici, doc. CLXXVIII; excerpt in AC, I/2, no. 330.

21 The suggestion that there is a connection to Cusanus' thinking on the legitimate representation of the universal Church and the role of majorities can be found in Meuthen's annotation to this passage in the Acta Cusana, as well as in WeRNER KRÄMER, «Der Beitrag des Nikolaus von Kues zum Unionskonzil mit der Ostkirche», Mitteilungen und Forschungsbeiträge der CusanusGesellschaft, 9 (1970), p. 34-52, here p. 50. Neither Meuthen nor Krämer cite specific works by Cusanus in this connection, but they may have had in mind his oration at the Diet of Frankfurt, delivered in June 1442. This includes passages in which Cusanus asserts that, with the departure of the most senior members of the Council, those gathered in Basel were canonically no longer capable of making conciliar decisions, irrespective of their numbers: "their error is arithmetical, and they come to conclusions through majorities without distinction [of persons] ». See THомаs M. Izвіскі (trans.), Nicholas of Cusa: Writings on Church and Reform, Harvard University Press, Cambridge - London 2008, p. 162-259, here, p. 237-239.

22 See $A C, \mathrm{I} / 2$, no. 349 
Trebizond in the dedication of his Latin translation of Plato's dialogue Parmenides, which he presented to Cusanus some time in the late $1450 \mathrm{~s}^{23}$

These are affirmative but largely circumstantial references. All other extant reports from participants simply do not attribute a speaking role to Cusanus, if they mention him at all. Sylvester Syropoulos, a senior official in the Greek Church who provided a detailed and vivid account of the Council and its preliminaries from the perspective of the Byzantines, ${ }^{24}$ described, for example, the arrival of the convoy in Constantinople in September 1437. He mentioned the head of the papal delegation, Marco Condulmer, as well as three «bishopambassadors »: Cristoforo Garatone, bishop of Corone; the bishop of Porto; and the bishop of Digne. ${ }^{25}$ But there is no indication of Cusanus here. In fact, throughout his entire account, which includes detailed descriptions of the discussions at the Byzantine court in those months, Syropoulos does not mention Cusanus at all, not even indirectly. ${ }^{26}$

A brief report to Eugenius IV from Constantinople dated 20 October 1437, sent jointly by the three minority representatives including Cusanus, speaks of the breakthrough in convincing the Byzantines, but gives little to no detail on how

23 Cited in AC, I/2, no. 329, fn. 14. On George of Trebizond and Nicholas of Cusa, see JoHN MonfasAni, George of Trebizond. A Biography and a Study of his Rhetoric and Logic, Brill, Leiden 1976 (Columbia Studies in the Classical Tradition, 1), p. 8-19; and JoHN Monfasani, "Cardinal Bessarion's Greek and Latin Sources in the Plato-Aristotle Controversy of the 15th Century and Nicholas of Cusa's Relation to the Controversy », in SPEER, STEINKRÜGER (eds.), Knotenpunkt Byzanz, p. 469-480, here p. 477-480.

24 Vitalien Laurent, Les 'Mémoires' du Grand Ecclésiarque de l'Église de Constantinople Sylvestre Syropoulos sur le concile de Florence (1438-1439), Centre National de la Recherche Scientifique, Paris 1971 (Publications de l'Institut français d'études byzantines, 3). For the English translation of chapter IV of Syropoulos's account, dealing with the journey from Constantinople to Italy and with the beginning of the Council proceedings, along with essays dealing with this segment, see the already cited KonDYLi et al. (eds.), Sylvester Syropoulos. On Syropoulos, who signed the unification decree at the Council of Ferrara-Florence in 1439 but soon thereafter renounced his support, see, in addition, the entry in ERICH TRAPP et al. (eds.), Prosopographisches Lexikon der Palaiologenzeit, vols. 1-12, Verlag der Österreichischen Akademie der Wissenschaften, Vienna 1976-1996, [hereinafter PLP], no. 27217. Among the extant manuscripts of Syropoulos's account, Laurent identified two versions, labelling them A and B, see LAURENT, Les 'Mémoires', p. 42-47 and p. 83-96. The B tradition offers a few additional details of interest to the discussion here, cited below where relevant. Contrary to Laurent's conclusions, it has since been argued that this represents an earlier stage of the text, see JAN LouIS VAN DiETEN, « Zu den zwei Fassungen der Memoiren des Silvester Syropoulos über das Konzil von Ferrara-Florenz. Die Umkehrung der These Laurents und die Folgen ", Annuarium historiae conciliorum, 11 (1979), p. 367-395. On the manuscript traditions see also, more recently, the discussion in KoLDITZ, Johannes VIII, p. 27-31.

25 LAURENT, Les 'Mémoires', p. 172-173.

26 A point already noted by Laurent in his annotations to Syropoulos: Ibid., p. 172, fn. 4, and by Bond, « The Historical Matrix », p. 140, fn. 26. 
this was achieved. ${ }^{27}$ In a more elaborate report delivered after the mission's return to Italy by the Bishop of Digne at the Council then in Ferrara, the only persons identified by name in the interactions with the Greeks are Cristoforo Garatone, as well as the Bishop of Porto and the Bishop of Digne himself, but not Cusanus. Multiple descriptions of the discussion in Digne's report simply refer to a collective or majestic « we $»{ }^{28}$ Furthermore, in the two brief missives sent from Constantinople by Cristoforo Garatone there is also no direct reference to Cusanus. ${ }^{29}$ Finally, one must consider the official reporting by the envoys of the Council majority faction, including by the aforementioned John of Ragusa, who mentions Nicholas of Cusa but merely notes his presence. ${ }^{30}$ Also significant here is a detailed, virtually day-by-day account by two ambassadors of the Basel majority presented on their return, in which they record the presence of Cusanus, but provide no indication of a specific role in the discussions, in contrast to the extensive attention given in their dispatches to Garatone and his role in the discussions. ${ }^{31}$

It seems clear from both the western and Greek sources that it was, in fact, Cristoforo Garatone, the Bishop of Corone, who did the heavy diplomatic lifting, more so than any of the other representatives. For one, Garatone already was Eugenius's representative and negotiator with the Byzantines, having been sent on previous missions to the Byzantine court (see below). ${ }^{32}$ The discussions in 1437

27 Joint letter of the Bishop of Porto, the Bishop of Digne and Cusanus to Eugenius IV, 20 October 1437, in AC, I/2, no. 331.

28 Report of 1 March 1438, presented in Ferrara, in CECCONI, Studi storici, doc. CLXXXVIII.

29 Garatone's reports in GIOVANNI MERCATI, Scritti d'Isidoro il cardinale Ruteno e codice a lui appartenuti che si conservano nella Biblioteca Apostolica Vaticana, Biblioteca Apostolica Vaticana, Rome 1926 (Studi e testi, 46), p. 118-119 and p. 120-123.

30 John of Ragusa, who was already in Constantinople when Garatone and the two bishops arrived in September 1437, presented his report to the Council of Basel in January 1438, see CECCONI, Studi storici, doc. CLXXVIII. The references to Cusanus are on p. DIX and Dx. On John of Ragusa and his role in Basel and in Constantinople, see, among others: JESSE MANN, Histories of the Council, in Decaluwé et al., Companion to the Council of Basel, p. 54-59; Helmrath, Das Basler Konzil p. 364370, 438; Petar VRankić, «Johannes von Ragusa im Ringen um die Teilnahme der Griechen am Basler Konzil », Annuarium historiae conciliorum, 27/28 (1995/96), p. 463-486; ANDRÉ TUILIER, « La mission a Byzanze de Jean de Raguse, docteur de Sorbonne, et le rôle des Grecs dans la solution de la crise conciliaire », in Bulletin philologique et historique, 1979, p. 137-152; as well as a brief biographical entry in PLP, no. 8574.

31 Report by the Bishops of Viseu and of Lausanne, February 1438, in JoHANNES HALLER, GUSTAV Beckmann, Rudolf Wackernagel, Giulio Coggiola (eds.), Concilium Basiliense. Studien und Quellen zur Geschichte des Concils von Basel, vol. V: Tagebücher und Acten, Helbling \& Lichtenhahn, Basel 1904, p. 277-362.

32 The only monograph on Garatone is LUIGI PESCE, «Cristoforo Garatone trevigiano, nunzio di Eugenio IV », Rivista di storia della Chiesa in Italia, 28 (1974), p. 23-93. See also Giacomo Moro, "Garatone, Cristoforo », in Dizionario Biografico degli Italiani [hereinafter: DBI], vol. 52, Rome 1999, p. 234-238, and PLP, no. 3550. Further references for Garatone below. 
were a continuation of those that Garatone had led before. The Byzantines themselves perceived Garatone as the architect of the agreement once it had been reached. Sylvester Syropoulos describes Garatone as the person « who had accomplished all the aforementioned things ", and underlines that he had already been sent to Constantinople by Eugenius three times. Moreover, Syropoulos recalls a scene on board one of the galleys to Venice, in which a senior Greek cleric addressed Garatone and complimented him on persuading the Emperor and the leadership of the Greek Church, suggesting that many rewards awaited him. ${ }^{33}$

The available documentation, in sum, does not provide a foothold for attributing a significant negotiating role to Cusanus. This should not be very surprising, given that it would have been unusual for a junior cleric to assume diplomatic precedence over an archbishop and three bishops. It is also not a new conclusion, as it has already been reached by a number of scholars (albeit not always with reference to all the evidence cited above). ${ }^{34}$ At the same time, it is not a conclusion that has always been fully embraced. Some of the literature has held on to the idea that Cusanus played an important or even leading role. ${ }^{35}$ Authors who advance this view often invoke the skills and knowledge that Cusanus could bring to the mission - his erudition, his knowledge of Church history, his interest in books, even his presumed knowledge of Greek - and posit that it was because of these skills that he was chosen for the task. ${ }^{36}$ To suggest a

33 LAURENT, Les 'Mémoires', p. 199; the same in English translation in KondyLi et al. (eds.), Sylvester Syropoulos, p. 188.

34 So also Marco Brösch, Walter Andreas Euler, Alexandra Geissler, Viki Ranff (eds.), Handbuch Nikolaus von Kues. Leben und Werk, Wissenschaftliche Buchgesellschaft, Darmstadt 2014, p. 50, which concludes: «Nach den erhaltenen Dokumenten stand Nikolaus nicht im Zentrum der Verhandlungen ». Similarly BonD, «The Historical Matrix », p. 140: «no proof that he played a serious role in the negotiations [...] or that he was directly instrumental in securing the Greeks' endorsement of the claims of the papal legation ».

35 So for example, EulER, « Nikolaus von Kues und die Ostkirche», p. 505 (see fn. 2 above), who concludes that the report by Rodrigo Didaci confirms Cusanus's own assessment of his role. Similarly: Morimichi Watanabe, Nicholas of Cusa. A Companion to his Life and his Times, ed. Gerald CHRISTIANSON, THOMAS M. IzBICKI, Ashgate, Farnham - Burlington 2011, p. 287, says that « Cusanus was engaged in the important task of persuading the Greeks to come to the Council of Ferrara ». Erich Meuthen saw confirmation of a preeminent part for Cusanus: see his annotation to $A C$, I/2, no. 329 n. 14. Edmond Vansteenberghe asserted that the Bishop of Digne and Cusanus (but not the Bishop of Porto?) succeeded in removing any remaining doubts on the part of the Greeks, and that John VIII came to accept Cusanus's views on the infallibility of the apostolic see: EdMOND VANSTEENBERGHe, Le Cardinal Nicolas de Cues (1401-1464): L'action - La pensée, Champion, Paris 1920, p. 62. Petro Bilaniuk, « Nicholas of Cusa and the Council of Florence ", Proceedings of the Patristic, Medieval and Renaissance Conference, 2 (1977), p. 59-75, provides a brief discussion of events in Constantinople, but none relating to the discussions with the Greeks.

36 For example, BRösch et al. (eds.), Handbuch, p. 51, after the conclusion mentioned in the footnote above, go on to underline that his proven skills as canonical lawyer, his knowledge of conciliar 
way forward in this debate, this paper will, rather than looking ever more closely at Cusanus himself, shift attention to the other members of the mission: the envoys, the galley commanders and the financiers. By exploring the undertaking from Eugenius IV's perspective and assembling a composite impression of the legation, one may subsequently consider how Cusanus may have fit into this broader picture.

\section{The nuncios}

\section{Marco Condulmer, Archbishop of Tarentaise. Legate de latere}

On 15 July 1437, shortly before the legation's departure from Venice, Eugenius appointed Marco Condulmer - Archbishop of Tarentaise, a fellow Venetian and a relative of the Pope - as nuncio apostolic and head of the mission. He gave him broad powers as legate de latere, "similar to those given to cardinals $" .{ }^{37}$ From other documents it appears that Eugenius intended such powers to include taking any necessary steps to block the efforts of the majority faction of the Council of Basel, including the power to excommunicate its members. ${ }^{38}$ There is no record that Marco Condulmer actually used, or threatened to use, these or

history, and his search for manuscripts in Constantinople would have played an important supporting role in the negotiations. MEUTHEN, Sketch for a Biography, p. 53, says that he owed his place to his fascination with the Greek language. BILANIUK, "Cusa and Council of Florence ", p. 64, suggests that Cusanus learned Byzantine theology and liturgy, and « since he knew Greek well ", he read the works of Greek Church Fathers as well as classical philosophers in the original language. And WaTANABE, Companion to his Life, p. 286, concludes that « his familiarity with the [Greek] language was no doubt one of the reasons why Cusanus was chosen to serve as a member of the minority group to visit Constantinople ». For the most recent contribution on the question whether Cusanus knew Greek, see JoHn Monfasani, "Nicholas of Cusa, the Byzantines and the Greek Language » in MARTIN THURNER (ed.), Nicolaus Cusanus zwischen Deutschland und Italien, Akademie Verlag, Berlin 2002 (Veröffentlichungen des GrabmannInstitutes zur Erforschung der mittelalterlichen Theologie und Philosophie. Neue Folge, 48), p. 215-252.

37 Eugenius IV's act giving Marco Condulmer authority as legate de latere published in CECCONI, Studi storici, doc. CLXVIII, and the same in Georgius HofmAnN (ed.), Concilium Florentinum. Documenta et Scriptores, Epistolae Pontificiae ad Concilium Florentinum Spectantes, vol. I, Pontificium Institutum Orientalium Studiorum, Rome 1940, no. 84. Marco Condulmer was also authorized to appoint, while on this mission, up to twenty-five persons as notaries under apostolic authority, i.e., to admit them to the officium tabellionatus, see Giongio Fedalto (ed.), Acta Eugenii Papae IV (1431-1447), e Vaticanis aliisque regestis collegit notisque illustravit, Pontificia Commissio Codici Iuris Canonici Orientalis Recognoscendo, Rome 1990, no. 588, p. 301-302. On legations in general, and the powers of a legate de latere, see Antonín Kalous, Late Medieval Papal Legation. Between the Councils and the Reformation, Viella, Rome 2017 (Viella History, Art and Humanties Collection, 3), in particular p. 55-102.

38 See the letter of 20 July 1437 from Eugenius to Marco Condulmer, in CECCONI, Studi storici, doc. CLIII. 
other measures in Constantinople against the ambassadors from Basel. The value of Marco Condulmer's authority as legate de latere may have been largely ceremonial in nature, raising his credentials in the eyes of the Byzantines, as it gave him a status equivalent to that of a cardinal and established him as direct agent of the Pope. In fact, the sources are remarkably quiet around Marco Condulmer, and his own voice is lacking from the records. There is no known report of the mission to Constantinople from his hand. All other participants make only occasional reference to him, ${ }^{39}$ in contrast to the picture that emerges of Cristoforo Garatone as an active negotiator. From Syropoulos we know, nevertheless, that Marco Condulmer was treated with honour and pomp upon his arrival in Constantinople. Syropoulos adds a poignant detail: during a solemn welcome procession through the city, Condulmer gave benedictions to the crowds - a grave diplomatic faux pas in the eyes of his Orthodox hosts. But presumably out of respect for Condulmer's status, the Byzantines chose to set aside their collective indignation, and raised the matter with him discreetly rather than in a confrontational way. ${ }^{40}$

The family relationship of Marco to Eugenius, that is, to Gabriele Condulmer, is not entirely clear. In the few studies where he is mentioned, he is referred to as Eugenius' nephew, based presumably on a passage in Syropoulos. ${ }^{41}$ A contemporary entry by the Venetian chronicler Antonio Morosini - which seems not to have been used on this point by modern studies - states that in 1431, immediately after his election as Pope, Eugenius IV drew a Marco Condulmer, son of a deceased and unnamed brother of his, into his immediate circle..$^{42} \mathrm{~A}$ modern biographical sketch asserts that Marco's father was a Bartholomeo Condulmer, ${ }^{43}$ although studies have not as yet identified a brother, or even cousin, of Eugenius by this name. ${ }^{44}$ The Condulmer family trees in Pompeo Litta's nineteenth century genealogical work of prominent Italian families suggests, in contrast, that his

39 The literature has followed the primary sources in this. Gill, for example, barely pays attention to Marco Condulmer, mentioning him by name only once (and then by first name only), and the three other times simply as «the Archbishop of Tarentaise ». See GILL, Council of Florence, p. 77, 79,80 and 82.

40 LAURENT, Les 'Mémoires', p. 175 and 609.

41 Ibid., p. 607. The studies that refer to Marco Condulmer as a nephew of the Pope do not indicate what source this is based on.

42 Andrea Nanetti (ed.), Il codice Morosini. Il mondo visto da Venezia (1094-1433), Centro Italiano di Studi sull'Alto Medioevo, Spoleto 2010 (Quaderni della Rivista di bizantinistica, 10), vol. III, p. 1526: «misier lo papa farde a preso uno altro so nievo in conpagnia, fiol condam uno so fradelo clamado fo misier Marcho Condolmer citadin de Veniexia».

43 ACHILle OlivieRI, « Condulmer, Marco », in DBI, vol. 27, Rome, 1982.

44 I am very grateful to Alan Stahl for sharing, by personal communication, preliminary findings of his extensive research into the branches of the Condulmer family, based on notarial and other records. No Bartholomeo or Marco of the right age and in immediate relationship to Gabriele Condulmer have yet been identified. 
father was a Nicolò Condulmer, a doctor, who was not directly related to Gabriele the later Pope..$^{45}$ Whatever the exact blood ties to Eugenius, it is of interest that the Marco Condulmer referred to in the aforementioned Morosini chronicle as a " citadin de Veniexia », ${ }^{46}$ that is, a non-patrician citizen of Venice, just like the Pope himself: contrary to assumptions sometimes made in the literature, Eugenius himself was not from a noble branch of the Condulmer family. ${ }^{47}$

The accounts are clearer with respect to Marco's affiliation with Gabriele Condulmer in church matters, and on the latter's role in Marco's career advancement. Marco was associated at an early age with the congregation of canons of Saint Giorgio in Alga in Venice, an Augustinian community established in 1400 by, among others, Gabriele Condulmer. ${ }^{48}$ In 1430, Marco was appointed by Pope Martin V as bishop of Avignon, a position he was confirmed in by Eugenius IV in $1432 .{ }^{49}$ This was not a happy experience: the citizens of Avignon rose in protest against his administration..$^{50}$ In early 1433, Eugenius moved him on to govern the papal city of Bologna, an experience that also ended in crisis. Marco Condulmer got entangled in the city's internal divisions, and was imprisoned for some time by rebelling citizens. ${ }^{51}$ These setbacks were apparently not an obstacle to his advancement, and Eugenius elevated him to the position of Archbishop of Tarentaise in November $1433 .{ }^{52}$ In the course of these years, Marco was present at the Council of Basel, siding with Eugenius in his confrontation with the

45 Pompeo LitTA, Famiglie celebri di Italia. Condulmero di Venezia, 1864. Digitalized version in the public domain by the Bibliothèque Nationale de France: <https://gallica.bnf.fr/ark:/12148/btv1b84523 537.r=?rk=3218900;0>, accessed on 6 October 2019.

46 See fn. 41 above.

47 Proof for this was provided by ReinHold C. MUelleR, « Sull'establishment bancario veneziano. Il banchiere davanti a Dio (secoli XIV-XV) », in GIORGIo Borelli (ed.), Mercanti e vita economica nella Repubblica Veneta (secoli XIII-XVIII), vol. I, Banca Popolare di Verona, Verona 1985, p. 47-106. The fifteenth century Greek historian Chalkokondyles already noted that it was only at the request of the Pope that (his branch of) the Condulmer family was admitted into the Venetian Maggior Consiglio, i.e, thereby elevating them to patrician status. See LaONiKos CHALKoKONDYLEs, The Histories, ed. and trans. AnTHONY Kaldellis, Harvard University Press, Cambridge, MA - London 2014 (Dumbarton Oaks Medieval Library), 2 vols., here vol. II, p. 35.

48 In addition to the entry in DBI, see JosEPH GILL, Eugenius IV. Pope of Christian Union, The Newman Press, Westminster 1961, p. 17-18. This biography - the only one available of Eugenius - should be used with caution for information about the Condulmer family and Gabriele's earlier years. Compare, for example, the essay by Reinhold C. Mueller, cited in the preceding footnote, with respect to Gabriele's commercial activities. A new, comprehensive biography of Eugenius IV would be desirable.

49 ConRadus Eubel, Hierarchia Catholica Medii Aevi, vol. II, Sumptibus et Typis Librariae Regensbergianae, Münster 1914, p. 100.

50 OLIVIERI, « Condulmer, Marco » in DBI; GILL, Eugenius IV, p. 45.

51 OlivierI, « Condulmer, Marco » in DBI; GILL, Eugenius IV, p. 67.

52 EuBEL, Hierarchia Catholica, vol. II, p. 245 
conciliarist faction. ${ }^{53}$ Although it is not clear whether he was present at the opening of the Council of Ferrara-Florence, or whether he took part in the deliberations, we find him as a signatory to the decree of union between the two Churches, adopted in July $1439 .{ }^{54}$ After his legation to Constantinople, further promotions effected by Eugenius followed: in February 1438, Marco was appointed as Patriarch of Grado, ${ }^{55}$ and later, in 1444, as Patriarch of Alexandria. ${ }^{56}$ In 1445, Eugenius placed him in a notable military command position, appointing him as apostolic legate for the renewed campaign against the Ottoman Turks, covering specifically Cyprus, Rhodes, Egypt and Syria, with extensive powers over both land and naval forces. ${ }^{57}$

Marco had prior experience in Greece. In 1429, he was deacon in the Venetianheld city of Patras in the Peloponnese. We know this thanks to the chronicle by George Sphrantzes (1401 - after 1477), righthand man to Constantine Paleologos, brother of the Byzantine Emperor, who led a Byzantine siege on Patras in that year. ${ }^{58}$ Marco Condulmer formed part of a delegation of citizens who met the Greeks, including Sphrantzes, outside the city to inquire as to their intentions. Years later, Sphrantzes recognized Marco when, in September 1437, he and Constantine Paleologos boarded the papal galleys in Euboea to travel with them to Constantinople..$^{59}$ It is possible that Marco Condulmer had learned Greek

53 See HelmRath, Das Basler Konzil, p. 115. References to the then Bishop of Avignon in the Council's protocols for 1432 in HALLER, Concilium Basiliense, vol. II, for example p. 136 and 146. Marco Condulmer does not appear as a participant in the protocols for 1434 through 1436, although efforts to secure his release in Bologna were on the Council's agenda in 1434, see HALLER, Concilium Basiliense, vol. III, p. 145-146, 154 .

54 Hofmann, Epistolae Pontificiae, p. 73.

55 EUBEL, Hierarchia Catholica, vol. II, p. 160.

56 Ibid., p. 85. Summarized text of the appointment by Eugenius IV, dated 16 December 1444, in FEDALTO, Acta Eugenii IV, no. 1224, p. 555.

57 See Fedalto, Acta Eugenii IV, no. 1227, 1 January 1445, p. 556-558. See also an entry in the apostolic accounts, dated November 1445, for the costs of twelve galleys outfitted at Marco Condulmer's behest, in NicolaI IORGA, Notes et Extraits pour servir à l'histoire des croisades au XV siècle, 3 vols., Ernest Laroux, Paris 1899, here vol. I, p. 91 (reference to «the patriarch of Alexandria », rather than a full name). Marco Condulmer's role in Eugenius' renewed efforts to launch a military expedition after the defeat at Varna in November 1444 has, to my knowledge, not yet been studied. IMBER, The Crusade of Varna, for example, does not mention Marco Condulmer at all, focusing instead on Cardinal Francesco Condulmer, vice-chancellor of the Pope and another relative of his, and on Francesco's role as legate and commander of the pontifical fleet in the 1444 campaign.

58 On Sphrantzes, see PLP, no. 27278. After the death of this brother in 1448, Constantine Dragases Paleologos became the last Byzantine Emperor. See PLP, no. 21500.

59 See George Sphrantzes, Chronicon Minus in Marios Philippides (trans.), The Fall of the Byzantine Empire: A Chronicle by George Sphrantzes, 1401-1477, University of Massachusetts Press, Amherst 1980, p. 36 (parlay outside the city walls of Patras, 1429) and p. 49 (recognition upon boarding the convoy to Constantinople, September 1437). Sphrantzes' surprise at seeing Marco again is palpable. On the siege of Patras, an archiepiscopal see, see Kenneth M. SETton, The Papacy and the 
during his time in Patras: while Sphrantzes recalls that there was an interpreter present during their encounter in $1429,{ }^{60}$ Syropoulos mentions that on the sea journey to Venice in 1437-1438, " the legate ", that is, Marco Condulmer, made a comment in Greek on the speed of the ship and the winds carrying them forward. ${ }^{61}$

Overall, the silence around Marco Condulmer in the sources relating to the 1437 mission gives rise to the impression of a ceremonial emissary, a figurehead, mostly noted for his loyalty to his relative the Pope, who had helped his career along in significant ways, and whom Marco had supported in the proceedings at the Council of Basel. ${ }^{62}$ That may also have been the extent of his role in Constantinople: not to be involved in the details of the negotiations, but to convey to the Byzantines, to the fullest extent possible, the authority and the person of Pope Eugenius IV: the former by Marco's rank and powers, the latter by his family relationship.

\section{Cristoforo Garatone, Bishop of Corone. Nuncio apostolic}

Cristoforo Garatone's key role in the negotiations in Constantinople in 1437 has already been noted. In both the Greek and Latin sources, Garatone eclipses the other legation members, including the legate himself, Marco Condulmer. Garatone's central role in the diplomacy towards the Byzantines is apparent not only during the debates in Constantinople. During the sea journey to Venice and upon arrival there, too, Garatone emerges from the sources as the Pope's chief executive and the main interlocutor for the Byzantine delegation. At a procession during a stop in the Venetian-held city of Modon (Methone), for example, Garatone took the place of distinction in accompanying the Greek patriarch. ${ }^{63}$ Garatone also handled large sums of money throughout the mission, ${ }^{64}$ addressed

Levant, vol. II, p. 32-35. Marco Condulmer held the function of deacon of Patras, at least on a titular basis, until January 1432, see EuBEL, Hierarchia Catholica, vol. II, p. 100. See also the brief entry on Marco Condulmer in PLP, no. 17078.

60 Sphrantzes, Chronicle, p. 36. The interpreter may have been for the sake of others on the delegation.

61 LAURENT, Les 'Mémoires', p. 209; KondyLi et al. (eds.), Sylvester Syropoulos, p. 199. This is the only indication in Syropoulos that he was on the same galley as Marco Condulmer on the journey to Italy.

62 This presents a marked contrast to the numerous and significant responsibilities that Eugenius IV entrusted to another relative, the above-mentioned Francesco Condulmer, who at the time of the legation of 1437 was already a Cardinal and camerlengo (treasurer) at the Curia, and who played a key role in designing and implementing Eugenius's eastern policies, including, as previously mentioned, legate and naval commander in the crusade of 1444. See ACHILLE OLIVIERI, "Condulmer, Francesco », in DBI, vol. 27 (1982), with extensive literature.

63 LAURENT, Les 'Mémoires', p. 205; KondyLi et al. (eds.), Sylvester Syropoulos, p. 195.

${ }_{64}$ See the numerous reimbursements to Garatone from the Camera Apostolica for his expenses in connection with the 1437 mission, in IORGA, Notes et Extraits, vol. II, p. 6-8. 
the Byzantines' financial demands and accommodation needs, and interpreted during (at least some) encounters with the doge of Venice and Pope Eugenius. ${ }^{65}$ This is an unusual combination of functions for an envoy: seeing to the wellbeing of the high-level guests, managing finances, facilitating communications, and personally engaging in high-level diplomacy. This no doubt speaks to Garatone's executive aptitude and diplomatic skills, and the immense trust Eugenius must have placed in him in keeping the Byzantines content and engaged on the path of unification.

As noted, Garatone's presence in Constantinople in 1437 was the culmination of a longstanding diplomatic effort by Eugenius. The Pope had dispatched Garatone to the East on three previous missions: in 1433, 1434, and in 1435. During these times, Garatone had already engaged directly, and successfully, with Emperor John VIII Paleologos and the Greek Patriarch on the issue of a council of union, as well as with the Armenian church.$^{66}$ While his rank and powers on the mission in 1433 are not unambiguously documented, we know that in 1434 Garatone was already sent with the authority of an apostolic nuncio. In the letter of instruction to Garatone, Eugenius addressed him as master of arts, and as his (Eugenius's) secretary.$^{67}$ Similarly, in a letter to the Council of Basel that looked back at Garatone's successful mission to the East in the 1433, Eugenius referred to him as the Pope's secretary, and underlined his Greek and Latin language skills. ${ }^{68}$ We know that by early February 1437 Garatone was still a canon of Padua. ${ }^{69}$ On these earlier missions, then, Garatone was not a senior cleric. But shortly before the 1437 mission, in February of that year, Eugenius made Garatone Bishop of Corone, possibly with the specific objective of elevating Garatone's rank on a subsequent visit to Constantinople. ${ }^{70}$

65 LAURENT, Les 'Mémoires', p. 205, 207, 223, and 231; KondyLi et al. (eds.), Sylvester Syropoulos, p. 196, 198,214 and 220.

66 His previous missions to Constantinople discussed, with source references, in KoLDITZ, Johannes VIII, p. 53, 55-57; HofmanN, «Die Päpstliche Gesandschaften», p. 57-61; PesCE, "Cristoforo Garatone », p. 31-37; GILL, Council of Florence, p. 52-53 (mission of 1433), p. 57-58 (mission of 1434), p. 59 (briefing the Council of Basel on success of 1434 negotiations), and p. 63-65 (mission of 1435); CECCONI, Studi storici, p. 58-92.

67 Cecconi, Studi storici, doc. XXVII, and Hofmann, Epistolae Pontificiae, doc. 36. Hofmann summarizes the titles or forms of address used to refer to Garatone in the official correspondence in HofmANN, « Die Päpstliche Gesandschaften », p. 60.

68 Ibid., doc. XXXI.

69 He is referred to as such in his appointment, by Eugenius IV, as Bishop of Corone on 27 February 1437, see FedAlto, Acta Eugenii, no. 490, p. 259, and below.

70 For the 1437 appointment, see preceding footnote. His predecessor, a Jacob Ziera, had recently died. A contemporary source suggests that Cardinal Francesco Condulmer, another relative of Eugenius IV, recommended Garatone's elevation to Bishop of Corone, see PESCE, «Cristoforo Garatone », p. 39-40. 
Garatone had risen from a humble background in Treviso, part of the Venetian terraferma. Born shortly before the end of the fourteenth century, he went on to study in Padua, where he crossed paths with well-known scholars and humanists of his day. ${ }^{71}$ To identify just one documented instance of an early connection to intellectuals and future leaders: we know that Garatone had studied Greek under one of the most-sought after teachers of Greek in Italy, Guarini da Verona, alongside Alberto da Sarteano, ${ }^{72}$ who, in 1439 , was sent by Pope Eugenius IV as apostolic nuncio to the Coptic Church in Egypt, ${ }^{73}$ and who later became Vicar-General of the Franciscan Order.

Before his service as papal point person, Garatone had accumulated extensive experience in Constantinople. From 1423 to at least 1428, he served there as notary and chancellor to the Venetian bailo, the resident representative in Constantinople. ${ }^{74}$ This was a prestigious administrative function that brought its office holders into close and continual contact with both the Venetian and Greek community, as it had for Garatone's predecessor in this role, the famous humanist Francesco Filelfo. ${ }^{75}$ One of Garatone's first acts in this position was to prepare the extension of the treaty between Venice and Byzantium regulating their trade relations: Garatone's name and function appear proudly among members of the Venetian and Greek elite who served as witnesses to the agreement. ${ }^{76}$ If his knowledge of Greek had not already been fully developed under Guarino, Garatone is likely to have polished his skills while posted for six or more years in Constantinople. It has been suggested, at least in connection with the humanist Francesco Filelfo, predecessor of Garatone as chancellor, that the responsibilities of this post left sufficient time for the pursuit of other

71 On his formative years, see PESCE, «Cristoforo Garatone », p. 26-29. The possibility that Cusanus and Garatone may have known each other from their studies in Padua has, to my knowledge, not yet been considered. Garatone graduated in 1420, and Cusanus arrived c. 1417-1418 and graduated in 1423, see Tom MüLlER, Der Junge Cusanus. Ein Aufbruch in das 15. Jahrhundert, Aschendorff, Münster 2013, p. 60-77.

72 In a letter to Garatone from 1443, Alberto da Sarteano makes reference to their playful student days under Guarino, see Franciscus Haroldus, Beati Alberti a Sarthiano. Opera Omnia, Giovanni Battista Bussotti, Rome 1688, p. 376.

73 Hofmann, Epistolae Pontificiae, doc. 195 of 26 July 1439.

74 Pesce, «Cristoforo Garatone », p. 29-30. On the functions of the bailo, see Chryssa Maltezou, 0

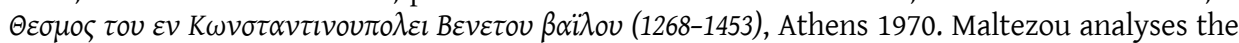
collection of documents known as the capitolare del bailo a Costantinopoli, in the State Archives of Venice - a miscellany of instructions, rules and practices relating to that office - and establishes a chronological list of office-holders for the period 1268-1453. Also relevant to the Venetian administration of its interests in Romania is FREDDY THIRIET, La Romanie Vénitienne au Moyen Age, E. De Boccard, Paris 1959 (Bibliothèque des écoles françaises d'Athènes et de Rome, 193).

75 THIERRY GANCHOU, "Les ultimae voluntates de Manuel et Iôannès Chrysolôras et le séjour de Francesco Filelfo à Constantinople », Byzantinistica, 7 (2005), p. 195-285.

76 Text of the treaty in Georg Thomas, Diplomatarium Veneto-Levantinum, vol. II, Venice 1899, no. 178, p. 341 . 
interests, including the study of Greek. ${ }^{77}$ It was presumably in Constantinople that Garatone began avidly collecting manuscripts, including Greek codices, some of which are known to have been copied at his request. ${ }^{78}$ In these efforts, he would have benefitted from an extensive network of contacts. ${ }^{79}$ There is indeed evidence that he was well connected to the Byzantine elite, including the later Greek patriarch, Georgios Scholarios. ${ }^{80}$

Some time after his service as chancellor in Constantinople in the 1420s, Garatone started working in close proximity to Eugenius. In 1432, Garatone was ordained as a priest and obtained a benefice from the Pope, and in that year or in early 1433 he took up a function as apostolic scribe and secretary to Eugenius, ${ }^{81}$ the function he was in when Eugenius sent him on his first mission to Constantinople in 1433. No conclusive records have been found to indicate how he first came to the attention of Eugenius, but it is possible that this was on the recommendation of Cardinal Francesco Condulmer, a relative of Eugenius IV, or

77 GANCHOU, «Les ultimae voluntates », p. 252. On Filelfo, Garatone and other Italians who traveled to Constantinople to study Greek, see AnNACLARA CATALDI PALAU, «Learning Greek in FifteenthCentury Constantinople», in Annaclara Cataldi Palau (ed.), Studies in Greek Manuscripts, Fondazione Centro Italiano di Studi sull'Alto Medioevo, Spoleto 2008, p. 219-234.

78 For Garatone's humanist interests and book collecting, see MERCATI, Scritti d'Isidoro, p. 109-116, and more recently PAOLA TOMÈ, «Cultura greca e Occidente latino: il caso di Treviso » in ANTONIO Lovato, Dilva Princivalli (eds.), Mondo latino e civiltà bizantina. Musica, arte e cultura nei codici del '400, CLEUP, Padova 2014 (Fonti e studi per la storia della musica veneta, 4), p. 41-78. Further on the identification of codices brought to Italy by Garatone and their places of origin, see Annaclara Cataldi Palau, "The manuscript production in the Monastery of Prodromos Petra (twelfth-fifteenth century) » in AnNa Cataldi Palau (ed.), Studies in Greek Manuscripts, p. 197-206; by the same author, "I colleghi di Giorgio Baiophoros: Stefano di Medea, Giorgio Crisococca, Leon Atrapes ", in Ibid, p. 303-344; and again the same, "Legature Costantinopolitane del monastero di Prodromo Petra tra i manoscritti di Giovanni di Ragusa », in Ibid., p. 235-280. A list of manuscripts owned by Garatone can be found in the online database Pinakes at $<$ https://pinakes.irht.cnrs.fr/>; accessed on 10 December 2019. Ganchou sees in Garatone a " grand pourchasseur de manuscrits dans le capitale byzantine ", and identifies a Georgios Chrysokokkes as the Greek copyist of a manuscript commissioned by Garatone, see GANCHOU, "Les ultimae voluntates», p. 244-245 and fn. 159, and p. 255 fn. 201. Important new archival material regarding Garatone's codices identified by KoLDITZ, Johannes VIII, p. 254. See also further below, for evidence that Garatone and Michele Zono, one of the financiers in 1437, knew each other from before the mission.

79 Garatone could have been a prime source of information for Cusanus on where to buy or commission manuscripts, for example at the monastery of Prodromos Petra, identified by Cataldi Palau as «the place to go when in Constantinople, for acquiring Greek manuscripts, having them copied and bound ", and as the confirmed source of at least some of Garatone's purchases, see CATALDI PALAU, « Learning Greek », p. 233.

80 See MARIE-Hélène Blanchet, Thierry Ganchou, «Les fréquentations byzantines de Lodisio de Tabriz, dominicain de Péra († 1435): Géôrgios Scholarios, Iôannès Chrysolôras et Théodôros Kalékas », Byzantion, 75 (2005), p. 70-103, in particular p. 91-93 and 98 for Garatone's time in Constantinople and his interactions with Georgios Scholarios. On Scholarios, see PLP, no. 27304.

81 PESCE, «Cristoforo Garatone », p. 31-32. 
other influential clerics at the curia from Treviso (like Garatone), such as Eugenius's relative Daniele Scoti, who was camerlengo at the curia starting in 1431, and whom Garatone may have known from either Treviso or Padua. ${ }^{82}$

After the adoption of the decree of union at the Council of Ferrara-Florence, Garatone accompanied the Emperor back to Constantinople in 1439, again in the capacity of nuncio, and remained there until 1441 on the instruction of Eugenius to see to the proper implementation of the decree of union..$^{83} \mathrm{He}$ was subsequently sent on four missions to Hungary, the last on behalf of Pope Nicholas V, with a key executive role in organizing a crusade against the Turkish forces in the Balkans. On his last mission there, Garatone died in the second battle of Kosovo in $1448 .^{84}$

What stands out regarding Garatone, in sum, is his extensive experience in Constantinople and in engaging with the Byzantines, his fluency in Greek, his prior and subsequent service to Eugenius IV, his connections to Venice, and the extensive trust the Pope placed in Garatone for handling some of the most significant and sensitive issues of his pontificate. It is also worth noting that Garatone, like Marco Condulmer and the Pope himself, was not a patrician.

\section{The commanders of the papal fleet}

The officers commanding the galleys to and from Constantinople were not members of the legation as such. Eugenius IV nevertheless appears to have understood that in order to bring the leadership of the Byzantine Empire and the Greek Church safely to Italy, arrangements for a secure sea transportation, as well as for the military protection of the city, were a priority. Indeed, they formed part of earlier commitments made by his predecessor, Martin V, in his negotiations with the Byzantines. Eugenius had four Venetian galleys armed and fitted out at papal expense, ${ }^{85}$ and he appointed Antonio Condulmer, a relative, as captain general with very broad powers to execute the mission (see below). In addition to the commander of the fleet and its flagship, there were three

$82 \quad$ Ibid., p. 27, 30-31.

83 Ibid., p. 44-46. For the appointment, see Fedalto, Acta Eugenii IV, p. 399, Hofmann, Epistolae Pontificiae, no. 219, p. 116.

84 Ibid., p. 47-55. In 1444, Garatone is to be found in these organizational tasks alongside Michele Zono, who, as noted below, was also a key figure in the 1437 mission; see IoRGA, Notes et Extraits, vol. II, p. 22.

85 Clearly stated by Eugenius himself in his letter of 6 July 1437, CECCoNI, Studi storici, doc. CLX, as well as numerous other sources. For probable reimbursements from the Camera Apostolica, including possible salaries to Antonio Condulmer, Alvise Bembo and Nicolò Contarini, see IoRGA, Notes et extraits, vol. II, p. 9. 
sopracomiti or galley commanders ${ }^{86}$ - one for each of the other three vessels serving under him. The process by which they were appointed, and whether this was left to the Pope or to Venice or settled through consultations, is not yet clear. The galleys were state-owned, ${ }^{87}$ and in June, July and August 1437 the Venetian Senate passed a number of directives with respect to this fleet, which are referred to in the Venetian records as the galleys of the Pope ${ }^{88}$ There is also a hint in an unpublished Venetian chronicle that the government of Venice had nominated at least two of the commanders as early as May $1437 .{ }^{89} \mathrm{~A}$ look ahead at the process followed in 1444, when Venice was outfitting a larger war fleet under papal authority and partially at his expense, may offer some insight: the six galley commanders, which included commanders who had served in 1437 and who are discussed in this paper, were formally appointed by the Venetian Senate upon the recommendation of the legate Cardinal Francesco Condulmer, on behalf of Eugenius. ${ }^{90}$ However, one cannot conclude with certainty that the same process was also followed in 1437, as the official records of the relevant Venetian institutions do not provide conclusive evidence of state involvement in the nominations of either the commanders of that year, or indeed the lower-ranking officers of the special papal fleet. ${ }^{91}$ Neither is there documented confirmation that Eugenius was directly involved in their selection, other than that of Antonio Condulmer. It is therefore possible that the broad powers given to Antonio Condulmer over the ships as well as its captains and other officers was understood to give him discretion in selecting them..$^{92}$ If so, it seems that

86 The role of Venetian naval officers discussed in LANE, A Maritime Republic, p. 50, and Alan M. Stahl, « Michael of Rhodes: Mariner in Service to Venice », in Pamela O. Long, David McGee, Alan M. STAHL (eds.), The Book of Michael of Rhodes. A Fifteenth Century Maritime Manuscript, vol. III, The MIT Press, Cambridge-London 2009, p. 35-98.

87 As all galleys were by the early $15^{\text {th }}$ century, see FRederic CHAPIN LANE, Venetian Ships and Shipbuilders of the Renaissance, John Hopkins University Press, Baltimore - London 1934 (repr. 1992), p. 14 and 101.

88 For discussions in the Senate in these months regarding the galleys and the Cretan troops, see: Venice, Archivio di Stato di Venezia [hereinafter ASV], Senato, Misti, reg. 60, fol. 22v; fol. 23v24r; fol. 28v; fol. 30v. A critical document is the instruction given on 9 June 1437 to Ermolao Donato, ambassador to Eugenius, to discuss the arrangements and Venice's contribution to the mission: ASV, Senato, Secreti, reg. 14, fol. 40r-40v. Also note the exchange with Garatone, who presumably appeared in person in the Senate on 17 July 1437, regarding the Cretan crossbowmen: Ibid., fol. 47v.

89 This is from an anonymous manuscript in the Foscarini collection in Vienna, known as the Diarii veneti dal 1412 al 1442, Vienna, Österreichische Nationalbibliothek, Lat. cod. 6205, fol. 102v. See also further below, under Alvise Bembo and Nicolò Contarini.

90 See ASV, Senato, Mar, reg. 1, fol. 226v. This included «Antonio Condulmer maior » and Nicolò Contarini, son of Gasparino.

91 After 1418, all such junior officers were chosen through elections held by the Collegio, see STAHL, « Michael of Rhodes, Mariner in Service to Venice », p. 66.

92 See the letter of 6 July 1437 to Antonio Condulmer, in CECCONI, Studi storici, doc. CXL. 
Condulmer started on this process before his formal appointment by Eugenius on 6 July, as there is evidence that already by 29 June a lower-ranking officer had been selected for one of the galleys. ${ }^{93}$

Irrespective of Eugenius's precise role in the selection of each commander directly or through Antonio Condulmer on his behalf - the profiles of all four are of importance to understand the composition and nature of the Constantinople mission. Aside from Antonio Condulmer, their names have come down to us not through instructions relating to the mission or reports of its participants, but through other fortuitous references. ${ }^{94}$

\section{Antonio Condulmer, captain general of the fleet}

Studies have assumed that Antonio Condulmer was another nephew of Eugenius. ${ }^{95}$ This is how Syropoulos refers to him. ${ }^{96}$ But none of the Western sources, including Eugenius's own instructions, identify him as such. ${ }^{97}$ In fact, Antonio must have been from another branch of the Condulmer family, and not

93 This follows from ASV, Collegio, Notatorio, reg. 6, fol. 178r: in June 1437, a « Nicolai de Judecca », civitus veneti, was elected to serve on the regular fleet of that year to Constantinople as comito and homo de conseio. On 29 June 1437, he was replaced by Giacomo di Roga after Nicolai had, instead, enlisted for service on the Pasqualiga, possibly in the same or a higher function. The entry from the Collegio's records, without reference to the papal galley, is also included in FREDDY THIRIET, Délibérations des Assemblées Vénitiennes concernant la Romanie, Mouton, Paris - The Hague 1971, vol. II, no. 1358.

94 In what follows, I apply the Venetian term Romania to refer to the Byzantine Empire, or what had been part of, which they considered a continuation of the Roman Empire, that is: parts of Greece, the Aegean islands, Constantinople, as well as beyond: the ports of Tana and Trebizond. It was closely associated with territories and harbours gained by Venice in the so-called fourth crusade of 1204. See FREDERIC C. LANE, Venice: A Maritime Republic, Johns Hopkins University Press, Baltimore - London 1973, p. 32 and p. 68.

95 So, among all other works consulted, LAUREnT, Les 'Mémoires', p. 172, fn. 4; GILL, Council of Florence, p. 82; KonDYLI et al., Sylvester Syropoulos, p. 187. This appears to have the extent to which biographical details of Antonio Condulmer have been traced in the literature. The entry in PLP,

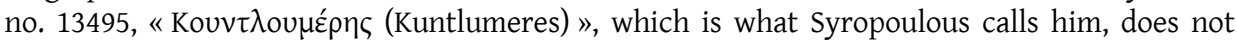
provide information beyond what is found in the latter's memoirs.

96 LAURENT, Les 'Mémoires', p. 176.

97 The reports of John of Ragusa, of the Bishop of Digne, and of the Bishops of Viseu and Lausanne mention «the captain », but give no name. Garatone does not mention him at all in his reports. In an entry for July 1431, Marin Sanudo the Younger mentions - albeit not in relation to the Constantinople mission - an Antonio Condulmer, "parente del Papa", see MARIN SANUdo IL Giovane, Le vite dei Dogi 1423-1474, ed. Angela Caracciolo Arico, Chiara Frison, vol. I: 1423-1457, La Malcontenta, Venice 1999, p. 95. This is the only contemporary Western source I have found that brings out the connection between an Antonio Condulmer and Eugenius. Sanudo indicates no family relationship when noting that the papal fleet being prepared in July 1437 was under the command of Antonio Condulmer, Ibid., p. 617. 
related by blood: Eugenius addresses Antonio as "nobilis vir $"{ }^{98}$ an honorific used exclusively for Venetian nobles, ${ }^{99}$ whereas, as noted above, Eugenius was not. ${ }^{100}$ There are further indications, mentioned below, that Antonio was a patrician. It would have been unheard of for a non-nobleman to command a state-owned Venetian galley or fleet. ${ }^{101}$

The documents relating to the Constantinople mission itself - the instructions from Eugenius, for example - do not provide us with a patronym or other identifying details. Nevertheless, references in other contemporary records to an Antonio Condulmer in this period are few, and all those that exist form a coherent picture, a plausible career path of one person. In 1413, an Antonio Condulmer son of Bernardo was entered into the Balla d'Oro, the annual lottery that provided a chance for young patrician men of at least eighteen years to enter the Maggior Consiglio at an earlier age than the default. ${ }^{102}$ Some years later, an Antonio Condulmer - without patronym - is recorded by the contemporary chronicler Antonio Morosini as patron, or commander, of a commercial cog to Syria in $1420,{ }^{103}$ of a cog to Valencia in $1422,{ }^{104}$ again to Syria in $1425,{ }^{105}$ in $1427,{ }^{106}$

98 See letter cited above, CECCONI, Studi storici, doc. CXL. Michael of Rhodes, a crewmember of the same fleet serving, refers to Antonio Condulmer as "egregius vir». See below, under Alvise Bembo, for source references for Michael of Rhodes. See also below, an entry for Antonio Condulmer in the prove di età for naval assignments in 1434.

99 I thank Reinhold Mueller for the observation that the Venetians were punctilious about honorifics, and would never use « nobilis vir » to describe or address a non-patrician.

100 Mueller, "Sull'establishment bancario veneziano », p. 90, citing archival sources on p. 103. A further indication of Gabriele Condulmer's status as citizen, rather than patrician, follows from Morosini who refers to him, in recording news of his election as Pope, as « citadin original de Veniexia ", see NANETTI, Il codice Morisini, vol. III, p. 1479.

101 See for a discussion of the role of nobles and non-nobles in Venetian naval enterprise, STAHL, "Michael of Rhodes: Mariner in Service to Venice », p. 40-41. For the privileges of nobility in international trade, see FREDERIC C. LANE, Andrea Barbarigo, Merchant of Venice. 1418-1449, Octagon, New York 1967 (repr.), p. 11-15.

102 ASV, Avogaria di comun, Balla d'Oro, reg. 162-I, fol. 52v. My identification of the relevant record of the Avogaria di comun here, as well as the one cited below, is thanks to the indexing by Rik van Hauwe: <www.rikvanhauwe.net/provedieta> accessed on 28 February 2019. The patronym would (in addition to the reference as «nobilis vir» in the 1434 record below) offer further indication that Antonio and Gabriele were not blood-related: an Antonio son of Bernardo has been identified in this period for the San Tomà branch of the Condulmer family, not the Santa Lucia branch to which Gabriele belonged. I again express appreciation here to Alan Stahl for sharing preliminary insights from his research into the Condulmer family. Pompeo Litta, in his nineteenth century genealogical study, states that Antonio son of Bernardo was the commander of the galleys carrying the Byzantines in 1437, i.e., a confirmation of the patronym, although Litta does not point to his sources. He also indicates without citing sources that Antonio's father Bernardo was a close friend (" amicissimo ») and cousin of Eugenius, the latter reference presumably used in a loose sense of the word. See LiTTA, Condulmero di Venezia.

103 NANETTI, Il codice Morosini, vol. II, p. 882.

104 Ibid., vol. II, p. 918. 
and presumably in $1428 ;{ }^{107}$ as commander of a galley to Flanders in $1429-1430 ;{ }^{108}$ and as captain of two cogs to Beirut in $1430 .{ }^{109}$ Both Morosini and Marin Sanudo record how, in 1431, shortly after Eugenius's accession, the Pope dispatched Antonio Condulmer from Rome to Venice with a large sum of money to procure three shiploads of wheat for Rome given the food shortages there, and to arm and command the galleys on the journey there - a first recorded instance of Gabriele Condulmer drawing on Antonio's services. ${ }^{110}$

Morosini also registers Antonio Condulmer as a commander of galley that formed part of a heavily armed guard fleet involved in a military engagement in 1432 against a Genoese flotilla which had been raiding Venetian-held islands in the Ionian and Aegean seas. ${ }^{111}$ The Venetian galleys sailed up to Pera in pursuit of the enemy ships, intending to strike at the Genoese colony across from Constantinople. Emperor John VIII had to intervene personally to avert bloodshed in the Byzantine harbour. ${ }^{112}$

In February 1433, the Senate informed Pietro Loredan, captain general of the armed fleet that year, that Eugenius IV had had two galleys armed and outfitted at his expense, to strengthen Loredan's forces. The Senate instructions identify Antonio Condulmer and Alvise Bembo (whom we will encounter again on the

105 Ibid., vol. II, 1097. For the same year, the coche Condulmaria - i.e., presumably the cog commanded by Antonio Condulmer, following the convention of naming a ship after its captain - is mentioned in instructions given by the Senate on 2 April 1425 to the commander general of a large Venetian guard fleet, Fantin Michiel: the Condulmaria is to join the armed fleet in an expedition in the Aegean, part of the conflict between Venice and the Ottomans over control of Thessalonica. See John R. Melville-Jones, Venice and Thessalonica 1423-1430: The Venetian Documents, Unipress, Padua 2002 (Archivio del litorale adriatico, 7), p. 102-103, citing ASV, Senato, Secreta, reg. 9 , fol. $5 \mathrm{r}-8 \mathrm{v}$.

106 NANETTI, Il codice Morosini, vol. III, p. 1191-1192 and 1226.

107 Morosini speaks of a « Chondolmera » active in September 1428, see Ibid., p. 1293.

108 Ibid., vol. III, pp. 1415, 1418, 1422, including commendable service during an attack by Catalan raiders.

109 Ibid., vol. III, p. 1426. Marin Sanudo says three cogs, to Beirut and Alessandria: SANUDo, Le vite dei dogi, p. 103-104.

110 SANUDo, Le vite dei Dogi, p. 95. NANETti, Il codice Morosini, vol. III, p. 1519.

111 NANETTI, Il codice Morosini, vol. III, p. 1643-1645. An Alvise Bembo, probably the same person by that name who was also on the 1437 mission, was another galley commander on this convoy, and was recognized by the state for meritorious service in this military engagement, see below.

112 Important details of this engagement come from a single source, an anonymous enkomion about Emperor John VIII Paleologos, translated and discussed in PETER SCHREINER, « Venezianer und Genuesen während der ersten Hälfte des 15. Jahrhunderts in Konstantinopel (1432-1434) ", Studi Veneziani, 12 (1970), p. 357-368. Morosini gives some details but the narrative is not easy to reconstruct. SANUDO, Le vite dei Dogi, also gives references (for example, p. 598-599) which underline the significance of the engagement, and includes Antonio Condulmer in the list of commanders who were involved (p. 108), but the events are scattered throughout the text and here, too, the chronology is hard to establish without reference to the Greek source published by Schreiner. 
1437 mission to Constantinople, see below) as the respective galley commanders. ${ }^{113}$ And in 1434, Antonio son of Bernardo Condulmer is recorded in Venetian acts as having met the age requirement of at least 30 years to serve as commander of one of the commercial galleys to Flanders, ${ }^{114}$ a verification process instituted in Venice in 1430.

From the chronology, it seems highly probable that all these were milestones in the career of one and the same person. They would show that, in addition to his (non-blood related) family ties to Eugenius, Antonio son of Bernardo Condulmer brought extensive naval and military experience to the papal mission of 1437, including experience in Constantinople.

Arriving in Constantinople in 1437, Antonio Condulmer displayed an aggressive approach that shocked the Greeks. When the Basel convoy appeared some days after the Venetian fleet, he prepared to attack it right there and then in the harbour. He had to be restrained by Emperor John VIII himself - a remarkable echo of the stand-off with the Genoese fleet in $1432 .{ }^{115}$ Condulmer claimed that he was under instruction to engage in battle with Basel galleys wherever he would find them, as they were enemies of the Pope. ${ }^{116}$ Eugenius's orders were broad but did not, in fact, mention initiating military engagement. ${ }^{117}$ All the more so, Antonio's actions suggest a fierce loyalty to Eugenius. In a separate, and unconfirmed instance implying both Antonio and Marco Condulmer in an alleged act of violence, a herald of the Council majority who had boarded their convoy in Crete had reportedly been tortured and killed during the voyage. The matter was brought to the attention of the Byzantine Emperor, who stated that upon investigation it appeared that the man had been taken back to Venice for trial, not murdered by either of the Condulmers. ${ }^{118}$

113 ASV, Senato, Secreti, reg. 12, fol. 69v, instructions of 23 February 1432 (more veneto, i.e. 1433).

114 ASV, Avogaria di comun, Prove di età per patroni di galere e altre cariche, reg. 177-1, fol. 60v: «Vir nobilis ser Antonius Condelmario quondam ser Bernardi qui vadit patroni Flandri probant etatem annorum XXX complitis ».

115 Laurent, Les 'Mémoires', p. 176. Also reported by John of Ragusa: CECCONI, Studi storici, doc. CLXXVIII, and by Rodrigo of Braga, see HofmanN, "Rodrigo, Dekan von Braga », p. 179. The Spanish traveller Pero Tafur, who encountered the Basel convoy in Chios on their return journey, also heard that the two convoys had almost come to blows in the harbour of Constantinople: Pero TAfur, Travels and Adventures 1435-1439, trans. and ed. Malcolm LetTS, Routledge, London 1926 (The Broadway travelers), p. 110-112. Tafur was also an eye-witness to the departure of the Venetian convoy from Constantinople on 25 November 1437, Ibid., p. 125, with on board John VIII and Cusanus.

116 LAURENT, Les 'Mémoires', p. 177, 179. The variant manuscript tradition designated by Laurent as « B » provides a few additional details of interest on this stand-off, including the note that it took two days to calm the parties down, and the names of the two harbours to which the Emperor assigned the convoys to separate them, see Ibid., p. 609, 611.

117 See the already cited letter of Eugenius of 6 July 1437, CECCONI, Studi storici, doc. CXL.

118 Reported by John of Ragusa, in CECCONI, Studi storici, doc. CLXXVIII, and by the Bishops of Viseu and Lausanne, in Ibid., doc. CLXXIX. Mentioned by GILL, Council of Florence, p. 82. 
The Pope's Agents in Constantinople

Just like Garatone, Antonio Condulmer continued to be engaged in senior executive functions in Eugenius's eastern policy after 1437. He was appointed as commander of the papal convoy that brought the Byzantines (accompanied by Garatone, see above) back to Constantinople after the Council of Ferrara-Florence in $1439 .{ }^{119}$ Furthermore, in 1444, Antonio commanded a galley in the heavily armed fleet dispatched by Eugenius under the overall leadership of Cardinal Francesco Condulmer. ${ }^{120}$ This was part of a major military campaign against the Ottomans, Eugenius's long-awaited crusade against the Turks. ${ }^{121}$

\section{Ettore Pasqualigo, galley commander}

The unpublished sixteenth century chronicle of the Venetian Stefano Magno identifies Ettore Pasqualigo as one of the three sopracomiti under Antonio Condulmer. ${ }^{122}$ He was in command of what a number of other sources refer to as

119 Attested by Michael of Rhodes, who served as lower-ranking officer on the same convoy. See Pamela O. Long, David McGee, Alan Stahl (eds.), The Book of Michael of Rhodes. A Fifteenth Century Maritime Manuscript, vol. 2: Transcription and Translation, MIT Press, Cambridge - London 2009, p. 278 (fol. 93b of the manuscript). Antonio Condulmer, son of the late Bernardo, is identified as the commander of this convoy in an unpublished record of payments to the officers and crew of the 1439 mission to Constantinople: ASV, Santo Spirito, Pergamene, fol. 4r. I thank Alan Stahl for sharing images of this manuscript with me.

120 Excerpt from the Senate decision in FREDDY THIRIET, Régestes des Déliberations du Sénat de Venise concernant la Romanie, vol. III, Mouton, Paris - The Hague 1961, no. 2638, p. 109. The full text of the decision identifies him as « Antonio Condulmer maior ", that is, with an epithet rather than a patronym, suggesting that by 1444 at the latest he had enjoyed a recognized reputation (possibly because of his naval engagements), and no longer needed identification as someone's son. See ASV, Senato, Mar, reg. 1, fol. 226v. Names of commanders also listed by SANUDo, Le vite dei Dogi, p. 398. Also serving as galley commander in this fleet was Nicolò Contarini, son of Gasparino, who was probably on the 1437 mission, see below.

121 The convoy did not manage to meet up with the land-based troops under the command of Cardinal Giuliano Cesarini, and the campaign ended in disaster for the Christian army at Varna. Among the extensive literature on the crusade of Varna, see SETTon, The Papacy and the Levant, vol. II, p. 82-90, and IMBER, The Crusade of Varna, passim.

122 SteFAno Magno, Annali veneti, Vienna, Österreichische Nationalbibliothek [hereinafter: ÖNB], Cod. Vind. 6214, fol. 74r: «Adi 4 Maggio [1437; presumably an error, as the decrees were adopted in Basel only on 7 May] uenne a Venetia dal Concilio Simon da Vale [Venetian ambassador to the Council of Basel] con un Tedesco [i.e., Cusanus], et un Francese [i.e. the Bishop of Digne], et un Portughese [i.e. the Bishop of Porto], Ambasciatori del Concilio, per montar sopra la galera, patron di quello Ettore Pasqualigo, armata delli danari del Papa ». For a discussion of the value of Magno's chronicle as historical source on the Council of FerraraFlorence, see SEBASTIAN KoldiTz, "The Council of Ferrara-Florence as Reflected in Venetian Chronicles: Preliminary Observations », in Sebastian Kolditz, MARKus Koller (eds.), The ByzantineOttoman Transition in Venetian Chronicles - La transizione bizantino-ottomana nelle chronache veneziane, Viella, Rome 2018 (Venetiana. Centro tedesco di studi veneziani, 19), p. 197-234, in particular p. 216-219. Marin Sanudo also records a Pasqualigo in the role of sopracomito, but does not have accurate information about the first name: SANudo, Le vite dei Dogi, p. 617. Sanudo 
the galea bastarda, an intermediate type galley, in contrast to the other three, which are identified as galee grosse. The Pasqualiga travelled separately from the other galleys both to and back from Constantinople. ${ }^{123}$ Presumably because of its greater speed, Pasqualigo's vessel played a particular role in the Pope's shuttle diplomacy of those months. It was his galley that transported Cristoforo Garatone and the Bishops of Digne and Porto in advance of the other three ships, stopping in Crete to arrange and pay for the crossbowmen that would be picked up by the other galleys for the city's protection, and arriving first in Constantinople. ${ }^{124}$ It was also Pasqualigo who left Constantinople a week before the others, departing on 19 November 1437, carrying with him as yet unidentified members of the Greek court, and arriving in Venice on 23 December. ${ }^{125}$ On board Pasqualigo's galley on the return voyage was the papal financier Michele Zono, who was quickly dispatched to Bologna after alighting in Venice to bring news to the Pope of the decision of the Byzantine. ${ }^{126}$ It was the swiftness of Pasqualigo and Zono that allowed Eugenius, based on the news from Constantinople, to declare the transfer of the Council from Basel to Ferrara as early as 30 December 1437, well before the Byzantine principals arrived in Venice in February.

correctly calls him Ettore Pasqualigo later on, in connection with the return to Venice, Ibid., p. 622.

123 Among other sources mentioning the type of galleys prepared at the request of Eugenius, and their different departure dates, see the information sent to the Venetian envoy to Emperor Sigismund on 12 August 1437, cited in IORGA, Notes et extraits, vol. III, p. 16. John of Ragusa reports the arrival in Constantinople, on 3 September 1437, of a galea dicta bastarda carrying the three bishops: CECCONI, Studi storici, doc. CLXXVIII. Ragusa does not identify the commander. The Bishop of Digne, in his report of 1438 , speaks of his journey on a galea subtile, also without mentioning the commander. He states that it departed from Venice on 26 July, stayed for four days in Crete, and arrived in Constantinople on 3 September: CECCONI, Studi storici, doc. CLXXXVIII. For a chronological overview of the comings and goings of the galleys, see annex 1 to this paper. Partial discussions in GILL, Council of Florence, p. 79-83, and KoLDITZ, Johannes VIII, p. 63-66. On Venetian galleys in general, including brief references to the galea bastarda type, see LANE, Ships and Shipbuilders.

124 See the sources quoted in the previous note.

125 Stefano Magno's chronicle reports the arrival in Venice on 23 December 1437 of Pasqualigo, Michele Zono and an unspecified number of members of John VIII's household: ÖNB, Cod. Vind. 6214 , fol. 76r. Marin Sanudo mentions the arrival of Ettore Pasqualigo in Venice twice. In the first, he explicitly refers to Michiel Zen or Zon, "nonzio del Papa ", arriving on the gallia Pasqualiga and hastening on from Venice to brief the Pope, see SANUDO, Le Vite dei Dogi, p. 150. In the second instance, Sanudo mistakenly dates the arrival to 28 December, and does not mention Zono, but specifies that on board the galley commanded by Ettore Pasqualigo were 70 persons affiliated with the Emperor Ibid., p. 622. See also IoRGA, Notes et extraits, vol. III, p. 22, fn.5, citing Magno as well as other chronicles.

126 Not previously pointed out in the literature: it was Michele Zono who carried a letter from John VIII to Eugenius IV, the only known correspondence from the Emperor to the Pope. The letter has been preserved. See further below, under the discussion of Michele Zono. 
An Ettore Pasqualigo son of Giovanni, of the contrada of Santa Marina, appears at least twice in the protocols and registers of the Venetian notary Vettore Pomino. ${ }^{127}$ One of these entries, from 1442, places Pasqualigo alongside Michele Zono as an adjudicator in a case that involved Cristoforo Garatone as a third party. This strongly suggests that the Ettore of the 1437 mission was indeed the son of Giovanni. In any event, no evidence of persons named Ettore Pasqualigo with another patronym appears in this period, and the positions held are internally consistent with the career of one person. It is therefore highly likely that all the references mentioned here are to one and the same Ettore Pasqualigo.

In 1418, Ettore Pasqualigo son of Giovanni married Elisabetta Zon, or Zono. ${ }^{128}$ She was the daughter of Pietro Zono, who in turn was a cousin of the aforementioned Michele Zono, financier of the 1437 mission. ${ }^{129}$ Ettore Pasqualigo is attested in the Morosini chronicle, among other instances, as galley commander of the Flanders fleet for $1422-1423 .^{130}$ In 1425, Ettore son of Giovanni Pasqualigo was a successful bidder in the auction to operate one of the three Venetian state-owned galleys to Romania ${ }^{131}$ He would have therefore commanded a ship to Constantinople, and possibly beyond, to Tana on the Sea of Azov, or Trebizond on the Black Sea, from late 1425 to early $1426 .{ }^{132}$ As noted, Cristoforo

127 ASV, Cancelleria inferiore, Notai, b. 148, [1433-1438], fol. 63v, and Ibid., [1435-1443], fol. 29v$30 \mathrm{v}$. KolDITZ, Johannes VIII, draws, among other sources, on the protocols of this notary to reconstruct the financial transactions in the period 1437-1438 involving Zono and Balthasar Lupari, see below.

128 Noted from an index of marriages at the Archivio di Stato di Venezia, which draws on the register of the Avogaria di comun, Matrimoni patrizi per nome di donna, as well as other sources: see GIUSEPPE GIOMo (ed.), Indice per nome di donna dei matrimoni dei Patrizi veneti, 086 ter/II (M-Z), p. 513, available online at <http://www.archiviodistatovenezia.it/siasve /cgi-bin/pagina.pl?Tipo=inventario\&Chiave=792>, accessed on 1 October 2019.

129 Emmanuele Antonio Cicogna, Genealogia della nobile famiglia Veneziana Zon pubblicata da Emmanuele A. Cicogna per festeggiare le nozze Marcello - Zon, Venice 1858. The connection between Elisabetta and Michele Zono is derived from comparing the three genealogical trees in this publication. Cicogna refers to the marriage of Elisabetta to Ettore Pasqualigo, but appears to be mistaken in calling him son of Marco. The Zono family did not, at that point, belong to the patriciate, but some of its members, such as Elisabetta Zono here and Michele Zono himself, appear to have married « up ».

130 NANETTI, Il codice Morosini, vol. III, p. 936, 938, 941-944, the latter page identifying the "galia nostra Pasqualiga » of the other entries as being under the command of Ettore Pasqualigo.

131 THIRIET, Régestes, vol. II, no. 1988, p. 227-228. Thiriet does not provide the patronym, but the full Senate record identifies him as «quondam ser Johannis ». So also Morosini for this same auction: «el nobel homo sier Ettore Pasqualigo fo de misier Zane ", see NANETTI, Il codice Morosini, vol. III, p. 1056-1057.

132 For the incanto system, see LANE, A Maritime Republic, p. 129-130, and in detail: DoRIS STÖCKLY, Le système de l'Incanto des galées du marché a Venise (fin XIIIe-milieu XVe siècle), Brill, Leiden 1995 (The Medieval Mediterranean, 5). Among a rich literature on Venetian interests in Tana and the Black Sea, see, for example, BERnARD Doumerc, «Les Vénitiens à la Tana au XVe siècle », Le Moyen Âge, 94 (1988), p. 363-379; SERGHEI KARPOV, « On the origin of medieval Tana » in $\Sigma \tau \varepsilon \varphi \alpha \mu o \varsigma$, Studia 
Garatone worked in Constantinople as chancellor to the Venetian bailo in this period, raising the possibility that they met there. The account book of the Venetian merchant Giacomo Badoer, which he maintained during his residence in Constantinople from 1436 to 1440, registers a small purchase of ship's netting by Ettore Pasqualigo in 1437, presumably at the time of the papal mission. ${ }^{133}$ Pasqualigo went on to serve in a large number of functions between 1440 and 1469 , including as Venetian bailo in Trebizond in 1441, and rising to Duke of Crete in $1455 .^{134}$

Ettore Pasqualigo, in short, was another commander who offered prior naval experience, including to Constantinople, and who continued to be associated after 1437 with one or more members of the mission, one of whom - Zono - he was directly connected to by marriage.

\section{Alvise Bembo, galley commander}

A further galley commander is identified, among other sources, by Stefano Magno's chronicle ${ }^{135}$, by the anonymous chronicle known as the Diarii veneti, ${ }^{136}$ and by one of the officers serving on the same ship, Michael of Rhodes. Michael states of himself in his unique handbook that he served in 1437 as a comito master of the oarsmen - on the papal galley under the nobleman Alvise Bembo, part of the fleet commanded by Antonio Condulmer on the mission to transport the Greek Emperor from Constantinople. ${ }^{137}$ A Lodovico (the equivalent of Alvise in Venetian naming conventions) Bembo - without patronym - is mentioned in

bizantina ac slavica Vladimíro Vavř́nek dedicata (Byzantinoslavica), 56/1 (1995), p. 227-235. See also further below for references on Venice's trade activities in Constantinople and beyond, fn. 156.

133 Giacomo BADOER, Il libro dei conti di Giacomo Badoer (Costantinopoli 1436-1440), eds. UMBERTo DoRini, Tommaso Bertelè, Istituto Poligrafico dello Stato, Rome 1956 (Il nuovo Ramusio, 3), p. 319 and 326. See also the indices to Badoer, published separately: GIACOMO BERTELÈ (ed.), Il libro dei conti di Giacomo Badoer (Costantinopoli 1436-1440). Complemento e indici, Esedra, Padua 2002 (Numismatica Patavina, 2).

134 Benjamin Kohl, Andrea Mozzato, Monique O'Connell, The Rulers of Venice, 1332-1524, <www.rulersof venice.org>, records 17123 and 16524, accessed on 1 October 2019. His career after 1454 is sketched in TESSA BEVERLY, "Venetian ambassadors 1454-94: an Italian elite ", Ph.D. Diss. University of Warwick 1999, p. 344.

135 ÖNB, Cod. Vind. 6214, fol. 74r: « Parti giorni 15 avanti le altre con Ambasciatori uno del Papa, l'altro dell'Imperator; Le altri partirono di Agosto, Capitano Antonio Condulmero, Sopracomiti Nicolo Contarini; et Alvise Bembo ».

136 Vienna, Österreichische Nationalbibliothek, Lat. cod. 6205, fol. 102v. He is identified as being from the confinio of San Salvador. The entry is for May 1437, suggesting that Alvise Bembo (and Nicolò Contarini, who is also mentioned) may have already been identified for a command role at that time.

137 Long, McGeE, STAhl (eds.), The Book of Michael of Rhodes, p. 278 (fol. 93a). The studies in volume III of this edition do not discuss Alvise Bembo, but provide extensive background information on Venetian seafaring. 
three entries in the ledgers of the Camera Apostolica, in May 1438, in connection with reimbursements for his role as patron of one the galleys that transported the Greeks; he appears alongside Antonio Condulmer and a third galley commander, Nicolò Contarini (see below). ${ }^{138}$ Morosini reports that Alvise Bembo was, like Antonio Condulmer, a galley captain in the military expedition in Greek waters against the Genoese in 1432, and that he was given a distinction for meritorious service on this mission. ${ }^{139}$ As already noted above, Alvise Bembo was, alongside Antonio Condulmer, commander of one of the two galleys outfitted in 1433 at Eugenius IV's expense to strengthen the Venetian guard fleet. ${ }^{140}$ An Alvise Bembo is attested in numerous entries of Giacomo Badoer's account book in Constantinople, for both 1436 and $1437 .{ }^{141}$ Most importantly, he is referred to there as patron of a galley which was there in October 1437, which had travelled there via Crete, and which was not affiliated with any regular fleet. There is little doubt that this was the papal convoy. ${ }^{142}$ Badoer refers to him at times as son of

138 See IoRGA, Notes et extraits, vol. III, p. 8. Briefly noted by both KoldiTz, Johannes VIII, p. 251, and THIERRY GANCHOU, "Le rachat des Notaras après la chute de Constantinople, ou les relations 'étrangères' de l'élite byzantine au XVe siècle ", in Michel Balard, Alain Ducellier (eds.), Migrations et diasporas méditerranéennes (Xe-XVIe siècle): actes du colloque du Conques, octobre 1999, Publications de la Sorbonne, Paris 2002, p. 149ff. One of three entries in the apostolic accounts notes that the payments to Bembo and Contarini were "pro galeis Tanas ", implying that they commanded not galleys of the papal convoy, but rather those of the regular Romania mercantile fleet. Kolditz and Ganchou follow Iorga in this interpretation. However, in light of the unambiguous identification by Stefano Magno and the Diarii veneti, as well as the statement by Michael of Rhodes that Bembo was his commander on the special papal convoy, this cannot be correct. Further evidence is in the Libro dei conti of Giacomo Badoer, which identifies the commander of the Romania fleet for 1437 rather as Zorzi Soranzo, with galley commanders Aluvixe Contarini, Aluvixe Diedo and Zacaria Donado, see BERTELÈ (ed.), Badoer. Complemento e indici, p. 77, s.v. galia de Romania.

139 NANETTI, Il codice Morosini, vol. III, p. 1643.

140 See above, fn. 113.

141 Aluvixe (Alvise) Bembo is mentioned almost 40 times, including in the following few examples, all from BADOER, Libro dei conti, p. 4, Aluvixe fo de ser Bianco, in Constantinople in 1436; p. 46, letter of exchange, November 1436; p. 55, letter of exchange, Aluvixe fo de ser Bianco, November 1436; p. 248, Aluvixe fo de ser Bianco, October 1437, this entry also identifies a Piero Vendilin as his homo de chonseio and a Donà Oxelo as his scribe, thereby adding yet two more identifiable names to the crew of the 1437 convoy; pp. 250 and 302, loading merchandise destined for Venice, 21 November 1437, which was possibly an infraction of the Senate's instructions of 30 July 1437 not to compete with the regular commercial fleet to Romania, see ASV, Senato, Misti, reg. 60 , fol. $28 \mathrm{v}$.

142 BADOER, Libro dei conti, p. 256. Crossbowmen were not the only cargo that Alvise picked up in Candia on the way to Constantinople: Badoer records the purchase from Alvise, in October 1437, of 27 bote of Cretan wine. This was another possible violation of the directive not to create competition for the regular Romania fleet, see previous footnote. Badoer sold some of the wine to the scribes of the galie di Provenzai, see Ibid, p. 178. This was undoubtedly, and ironically, the convoy of the Basel majority, under the command of the Governor of Nice (Provence), Nicod the Menthon; Sanudo also calls them the galie d'i Provenzalli, see NANETTI, Le vite dei Dogi, p. 145. For 
Bianco, therefore securely identifying his patronym. 'Bianco' was a nickname: in 1428, an Alvise Bembo, son of the late "Laurentius dicti Blanco », was formally presented for the Balla d'Oro, the annual lottery to enter the Great Council before the age of twenty-five. ${ }^{143}$

An entry into a Venetian state account dated April 1443 refers to a payment to Alvise Bembo as commander of a galley of the Pope, ${ }^{144}$ possibly part of the preparations for Eugenius's crusade against the Turks, as this account related to numerous other related dealings. ${ }^{145}$ (It is not certain, however, whether he ultimately took part in the crusade of 1444 , as his name does not appear in the list of persons to be appointed for command of a Venetian galley in March of that year). ${ }^{146}$ Other assignments after 1437 included command of Venice's armed fleet in the Adriatic and Aegean - the galere del Golfo - in 1446, ${ }^{147}$ command of the galere di Barberia in 1447, ${ }^{148}$ and of a smaller, ad hoc guard fleet in $1448 .{ }^{149}$

It may be concluded that in 1437, Alvise Bembo - like Antonio Condulmer and Ettore Pasqualigo - had been to Constantinople before; that he had previously commanded a galley outfitted by Eugenius IV; that he had sailed alongside Antonio Condulmer on at least two occasions; and that after 1437 he returned to serve on at least one further major papal mission involving Venetian galleys.

\section{Nicolò Contarini, galley commander}

The identification of the fourth and final galley commander, Nicolò Contarini, is also based on the chronicle of Stefano Magno ${ }^{150}$ as well as the account books of the Apostolic Chamber. ${ }^{151}$ Neither of these sources, again, provide a patronym. The Contarini were a particularly large family, and the records show multiple persons named Nicolò at that time, making a positive identification more difficult

an account of that convoy's preparation and journey (not including Cretan wine), see WiLLY CoHN, «Die Basler Konzilsflotte des Jahres 1437 », Basler Zeitschrift für Geschichte und Altertumskunde, 12 (1913), p. 16-52.

143 ASV, Avogaria di comun, Balla d'Oro, reg. 162-I, fol. 196r. The identification of Alvise's father as Bianco Bembo was already posited by GANCHOU, «Le rachat des Notaras », p. 183, but without the evidence provided above.

144 ASV, Collegio, Notatorio, reg. 8, fol. 180v.

145 See Reinhold C. Mueller, The Venetian Money Market. Banks, Panics, and the Public Debt, 1200-1500, Johns Hopkins University Press, Baltimore - London 1997, p. 197, fn. 143.

146 ASV, Senato, Mar, reg. 1, fol. 226v for 23 March 1444, cited above in connection with the appointment of Antonio Condulmer on this mission.

147 Benjamin Kohl, Andrea Mozzato, Monique O'Connell, The Rulers of Venice, 1332-1524, <www.rulersof venice.org>, record 16885, accessed on 28 February 2019. Record for Ludovico Bembo, son of Bianco.

148 KoHL ET AL., The Rulers of Venice, record 17048, accessed on 28 February 2019.

149 THIRIET, Régestes, vol. III, no. 2765, p. 142-143, for 4 March 1448.

150 ÖNB, Cod. Vind 6214, fol. 74r, cited above.

151 IORGA, Notes et extraits, vol. III, p. 8. 
than for the other commanders. A few examples may suffice: a Nicolò Contarini son of Alvise, was attested as being 25 years in 1431, and entered the Maggior Consiglio that year. A Nicolò Contarini son of Pietro did so in 1433, and served as bowman on the Beirut fleet in 1434. Morosini mentions a Nicolò son of Girolemo as commanding a cog to Crete in $1423 .{ }^{152}$

Badoer includes numerous entries in his Constantinople account book for a Nicolò Contarini, without patronym, and these may in fact involve two different persons. The first of Badoer's entries is for a galley commander in Constantinople in 1436, a likely match for the galley commander of $1437 .{ }^{153}$ All others relate to a Nicolò Contarini who was not a commander and who seems to have operated frequently out of Salonica. For the period after 1437, a record of the Venetian Senate attests to a Nicolò Contarini son of Gasparino as one of the six galley commanders appointed at the request of Eugenius as part of the military campaign against the Ottomans in $1444,{ }^{154}$ which, as we have seen, also included Antonio Condulmer as sopracomito.

If this was the same Nicolò as of the 1437 mission, it would establish a tantalizingly close connection to Eugenius himself: in 1420, Nicolò Contarini son of Gaspare married Caterina Condulmer, daughter of Simone Condulmer, brother of Gabriele, i.e., the later Eugenius IV. ${ }^{155}$ In the absence of further information, however, about the patronym of the Nicolò who served as sopracomito in 1437, one cannot conclude with certainty that he was, indeed, the husband of the Pope's niece.

Despite some difficulties in identifying Nicolò Contarini, the overall picture that emerges from the biographical details of the commanders is that authority on Eugenius's galleys was in the hands of four Venetian noblemen who had prior and often extensive naval command experience. At least three, and possibly all four, had been to Constantinople before 1437. Eugenius could count on officers who knew the waters of Romania, and who knew what it meant to command a galley. Two of them - Antonio Condulmer and Alvise Bembo - had even served together on a military operation in the seas of Romania, including a near-attack

152 NANETTI, Il codice Morosini, vol. III, p. 1052.

153 BADOER, Libro dei conti, p. 28

154 THIRIET, Régestes, vol. III, no. 2368, p. 109. Also noted in other sources by IoRGA, Notes et extraits, vol. III, p. 156-157, fn.1. For the patronym, which these collections do not provide, see the underlying record: ASV, Senato, Mar, reg. 1, fol. 226v.

155 Noted from an index of marriages at the Archivio di Stato di Venezia, see, see Giomo (ed.), Indice per nome di donna, 086 ter/I (A-L), p. 121, available online at <http://www.archiviodistatovenezi a.it/siasve/cgi-bin/pagina.pl?Tipo=inventario\&Chiave $=792>$, accessed on 1 October 2019. See also the testament of Nicolo Contarini, son of Gaspare, of the confinio of St. Felix, in which he refers to his wife Caterina, without indicating her maiden name, as well as a son Gabriele, perhaps named after Caterina's famous uncle, in ASV, Notarile, Testamenti, b. 923 (notaio Marino de Sori), no. 27, 7 August 1456. 
on Pera, in 1432, and subsequently in 1433 on two galleys commissioned and paid for by Pope Eugenius IV as reinforcements of the Venetian guard fleet. One of them - Ettore Pasqualigo - was connected by marriage to one of the financiers, Michele Zono, and may have known Cristoforo Garatone from Constantinople in 1425-1426. Pasqualigo also continued to have some documented relationship to both of them after 1437. There is a possibility that the fourth commander, Nicolò Contarini, was directly connected to Eugenius by marriage. Finally, at least two, and possibly three, of the four commanders took part in the 1444 crusade or its preparations, again in command of Venetian galleys commissioned by the Pope.

\section{The financiers}

The conclusion that Eugenius engaged highly experienced people for the task, including with experience in Romania, and people who were already known or affiliated to him, can be established in even greater detail for the two so-called financiers, Michele Zono and Balthasar Lupari. Both can be shown to have had a network in Constantinople that would have been of value on this mission. ${ }^{156}$ Striking about their profiles, in addition to their experience in the East, is how rooted they were in Venice and Venetian affairs, and the fact that they were given such critical roles in the geopolitics of their day as non-patricians.

Eugenius tasked them on 7 July 1437 to raise the funds required, in Constantinople and elsewhere, to bring the Greeks to Italy. ${ }^{157}$ The commission includes specific references to the costs of the galleys needed for the transport, and of the crossbowmen for the defense of Constantinople. Recent research has provided important new insights into the role of these two men in the myriad transactions in Constantinople, which are also key to understanding the costs of

156 Among the extensive literature on the Venetian community in Constantinople, and on Venice's trade with, and in, the Byzantine Empire, including in the first half of the Quattrocento, see, most recently: AlESSIO SOPRACASA, Costantinopoli e il Levante negli atti del notaio veneziano Giacomo dalla Torre (1414-1416), Istituto Veneto di Scienze, Lettere ed Arti, Venice 2015, notably p. 134-186; Nevra NecipoĞLu, Byzantium between the Ottomans and the Latins. Politics and Society in the Late Empire, Cambridge University Press, Cambridge 2009, in particular p. 184-234; THIERRY GANCHOU, « Giacomo Badoer et Kyr Théodôros Batatzès, 'chomercier di peso' a Constantinople (flor. 14011449)», Revue des Études Byzantines, 61 (2003), p. 49-95; KLAus-Peter MatsChKE, « Some Merchant Families in Constantinople Before, During and After the Fall of the City 1453 ", Balkan Studies, 38/2 (1997), p. 119-238; and Nicolas OiKonOMIDEs, Hommes d'affaires grecs et latins à Constantinople (XIIIe-XVe siècles), Institut d'études médiévales Albert-le-Grand - J. Vrin, Montreal - Paris 1979 (Conférence Albert le Grand, 1977). These and other studies underline the interconnectedness between the Italian, Byzantine and other communities, including Jews and Muslims. With the exception of SOPRACASA, Giacomo dalla Torre, who briefly refers to Michele Zono (p. 471-472), these studies do not mention the two merchants of interest here (but see literature references for KolditZ and HALFF).

157 CECCONI, Studi storici, doc. CXLI; Hofmann, Epistolae pontificiae, no. 77. 
the Council of Ferrara-Florence overall. ${ }^{158}$ While the financial intricacies in Venice and Constantinople, and thereafter in Ferrara and Florence, are still not fully understood, it is clear that the two men were not bankers in any modern sense. Instead, the records show a diversity of transactions in which they sometimes put up some amounts of money themselves, but more frequently acted as middlemen between various Venetian lenders in Constantinople and the papal treasury, through the use of letters of exchange. ${ }^{159}$ Their use would have required trusted, personal contacts in Constantinople.

\section{Michele Zono}

Of the two, Michele Zono, a non-noble Venetian, ${ }^{160}$ appears to have had the most active role in the financial matters, handling very large sums, including in cash, to cover the expenses of the papal convoy, the costs of the Cretan crossbowmen, as well as the living expenses of the Greek officials traveling to Italy. But Zono did more than handle finances. He travelled on the galea Pasqualiga that returned to Venice before the others, almost certainly carrying a letter from John VIII to Eugenius IV, in which he informed the Pope that he would embark on the papal galleys within a few days of writing. ${ }^{161}$ The letter was a critical development, and from Venice Zono left immediately for Bologna to deliver the news to Eugenius. ${ }^{162}$ While John VIII may not have felt committed to one council location or another before his arrival in Italy, ${ }^{163}$ the missive significantly strengthened Eugenius'

158 Kolditz has followed the money in the archival records in great depth, including the roles of Zono, Lupari and Garatone, see KolDITZ, Johannes VIII, in particular p. 244-254, thereby expanding on notices gathered earlier by IoRGA, Notes et extraits, vol. III, p. 5-7, and on the study by JosePH GILL, "The Cost of the Council of Florence », in JosEPH GiLL, Personalities of the Council of Florence and other Essays, Barnes \& Noble, New York 1964, p. 186-203. Balthasar Lupari's life and career, and his connection to Nicholas of Cusa, have been traced in detail in HALFF, "Did Nicholas of Cusa Talk with Muslims? ».

159 Kolditz, Johannes VIII, p. 250 and 254. Eugenius' commission of 7 July 1437 referred to such letters of exchange, see note above.

160 He often appears in the records related to the Council of Ferrara-Florence as Michele, Michaele or Michiel Zeno, suggesting a heritage from one of the patrician families of Venice. But it has been established that his family name was Zono, that is, from a non-noble line. See KoLDITZ, Johannes VIII, p. 246. The family was later elevated to patrician status, see CICOGNA, Genealogia della nobile famiglia Veneziana Zon.

161 The letter, published in HofmanN, «Rodrigo, Dekan von Braga », p. 186, was cited above. It is dated 18 November 1437, a day before Pasqualigo's and Zono's departure. The Emperor refers explicitly to Michele Zono and praises him. This is the only extant letter from the Emperor to the Pope. The connection between this letter and the journey of Zono on Pasqualigo's galley has not been previously noted.

162 ÖNB, Cod. Vind. 6214, fol. 76r.

163 GILL, Council of Florence, p. 102, and DeCALuwÉ, Successful Defeat, p. 281, discuss the continuing hesitations of the Byzantines after their arrival, in light of the divisions between the Pope and the Council in Basel. See also Vera Andriopoulou, «The Logistics of a Union: Diplomatic 
hand in the conflict with the Council of Basel. On 30 December 1437, Eugenius issued the bull Pridem ex justis, boasting that John VIII was on his way in one of the Pope's galleys, and reaffirming Eugenius's earlier decision to transfer the Council of Basel to Ferrara. ${ }^{164}$ Within days, the Council of Ferrara opened. ${ }^{165}$ The fact that such a politically vital dispatch was given to Zono speaks of the trust he must have enjoyed by both the Emperor and the Pope. Indeed, in the letter, John VIII singles out Zono for his reliability as source of information, pointing to the fact that he knew him personally.

An earlier connection between Zono and Eugenius, as well as between Zono and Cristoforo Garatone, is documented for 1435. In that year, the Pope appointed him as scutifer honoris and as familiaris, honorific titles designating him as «shieldbearer » and as member of the papal household. The relevant act was drafted by none other than Cristoforo Garatone. ${ }^{166}$ Moreover, Michele Zono had extensive experience in Romania and the Black Sea area. In 1408, Zono was appointed as agent for a relative's business in Tana and other parts of Romania. ${ }^{167}$ Records attest to his presence again in Tana in 1413 and $1414,{ }^{168}$ and then in Constantinople in 1417. ${ }^{169}$ Further archival records indicate that Zono was in Constantinople in 1426 and $1427 .{ }^{170}$ It is therefore possible that he met Garatone at that time, then chancellor of the Venetian bailo. A close affiliation to the office of the bailo, and indeed instances in which Zono represented Venetian state interests of the highest order, is attested for in subsequent years: in April 1430, we find him on a mission to the Ottoman Sultan in Adrianople at the request of the bailo, authorized to negotiate a deal with the Turks in connection with their siege of Venetian-held Thessalonica, a last-minute effort that did not avert the Ottoman take-over. ${ }^{171}$ And in 1431, Zono was one of the four witnesses on the

Communication through the Eyes of Sylvester Syropoulos", in KonDYLI et al., Sylvester Syropoulos, p. 49-67, for the argument that it was not until John VIII's arrival in Italy that the Emperor truly committed to the papal invitation.

164 Eugenius' bull in CECCONI, Studi storici, doc. CLXX. Discussed in GiLL, Council of Florence, p. 94-95.

165 Ibid., p. 94-97; DeCALuWÉ, Successful Defeat, p. 282-283.

166 KolDITZ, Johannes VIII, p. 247-248.

167 Ibid., p. 246. The record identifies him as Micaelo Zono quondam ser Nicolai confinii Sancte Marine.

168 Ibid., p. 246

169 Ibid., p. 247

170 For July 1426: a transaction recorded in Constantinople and witnessed by Francesco Filelfo, albeit no longer as chancellor of the bailo: ASV, Duca di Candia, b.1, fasc. 13, fol. 19v. (This would also suggest that Zono and Filelfo knew each other). In September 1427, Zono appears as witness in a case reported by another chancellor of the bailo (not Cristoforo Garatone): ASV, Duca di Candia, b.1, fasc. 13, fol. 40v. While the activities of Filelfo in Constantinople lie beyond the scope of this paper, the above-cited manuscript of 1426 in the fondo of the Duca di Candia in Venice adds a new fragment to the extensive discussion in GANCHOU, "Les ultimae voluntates ».

171 IORGA, Notes et extraits, vol. I, p. 516-518. Iorga summarizes the official instructions to the Venetian captain-general which refer to Zono's presence in Adrianople, but gives an incorrect source: this should read ASV, Senato, Secreti, reg. 11 (1429-1431), fol. 102v, (not Senato, Misti, 
Venetian side to the extension of the state treaty between Venice and Byzantium, prepared and signed in Constantinople. ${ }^{172} \mathrm{He}$ is mentioned once in the account book of Giacomo Badoer, placing him in Constantinople in November $1436 .{ }^{173}$

Some time in or before 1440, Eugenius rewarded Zono for his services by awarding him the honorific title of comes palatinus or palatine count. ${ }^{174}$ Zono reprised his role as financial middle-man for the Pope in the preparations for Eugenius's crusade against the Ottomans in 1444 and in the years that followed the defeat at Varna, again handling large sums of money, including withdrawals of cash from Venetian banks, often in collaboration with Cristoforo Garatone. ${ }^{175}$ An inscription at the church of Sant'Andrea della Certosa in Venice, now lost, commissioned by a descendant of Zono in 1544, celebrated Zono's role in supporting Eugenius's 1444 expedition against the Turks, underlining his status as comes palatinus. ${ }^{176}$

As noted above, Ettore Pasqualigo was married to Michele Zono's cousin's daughter. The records show a continued commercial connection between Pasqualigo and Zono after 1437. Among other evidence, Zono took on a commission as agent of Ettore Pasqualigo and others in 1440, ${ }^{177}$ and served on an arbitration panel with him in $1442 .{ }^{178}$ Zono must also have remained in very close contact with Garatone: Zono inherited manuscripts from Garatone's library after the latter's death in 1448, manuscripts which eventually entered into the Vatican collection. ${ }^{179}$ In addition to attesting to a very close relationship, Garatone's gesture suggests that Zono was highly literate, possibly even speaking Greek.

reg. 57, fol. 101-102). For the Venetian domination of Thessalonica from 1423-1430 and the Ottoman conquest in 1430 see, NECIPoĞLu, Byzantium between the Ottomans and the Latins, p. 103115; Nicol, The Last Centuries of Byzantium, p. 347-350, and in detail, SETTON, Papacy and the Levant, vol. II, p. 44-81.

172 Text in Georg Thomas, Riccardo Predelli (eds.), Diplomatarium Veneto-Levantinum, vol. II, Venice 1899, p. 346. The treaty is discussed in Donald M. Nicol, Byzantium and Venice. A Study in Diplomatic and Cultural Relations, Cambridge University Press, Cambridge 1988, p. 373.

173 BADOER, Libro dei conti, p. 66. He appears as « Michiel Zion ».

174 Eugenius addresses him as such in October 1440, see HofmAnn, Epistolae Pontificiae, vol. III, no. 244, p. 21. Also KoldiTz, Johannes VIII, p. 256.

175 See Mueller, The Venetian Money Market, p. 197-198. Also (among other references to his financial role): IORGA, Notes et extraits, vol. II, p. 22-26, and, for 1445, vol. III, p. 203. Furthermore, THIRIET, Délibérations, no. 1406, p. 178 (14 September 1445).

176 Emmanuele Antonio Cicogna, Delle inscrizioni Veneziane, vol. II, Giuseppe Picotti, Venice 1827, p. 89. Cicogna underlines the close bond between Zono and Eugenius, drawing on a further source to highlight his status as scutifer of the Pope.

177 ASV, Cancelleria inferiore, Notai, b. 149 (Vettore Pomino), 1439-1442, fol. 54v, dated 30 August 1440.

178 Ibid., 1435-1443, fol. 29v-30v, dated 3 December 1442. The case involved property of Jacob Ziera, late Bishop of Corone, and immediate predecessor of Cristoforo Garatone in that role, who is also mentioned in the process as a third party.

179 KoldiTZ, Johannes VIII, p. 256. 


\section{Balthasar Lupari}

For Balthasar Lupari, who, like Zono was deeply involved in the financial support for the undertaking, there is also ample evidence of being well connected to Constantinople and its residents. ${ }^{180}$ One such piece of evidence is provided by Cusanus, in a brief personal glimpse from his days in Constantinople. ${ }^{181}$ Cusanus refers to him by name in his preface to the Cribratio Alkorani, as a source of information on Muslims. ${ }^{182}$ Lupari had turned to Cusanus to help a group of thirteen eminent Turks in Constantinople who wished to convert and become "fully instructed» by the Pope in Rome, if transportation could be made available to them. The anecdote suggests that Lupari moved in networks of not just Western merchants. There is further evidence that Lupari was a frequent visitor of Constantinople, and probably a longer-term resident at times. A notarial act in the Bologna archives refers to a purchase of a slave by Balthasar from a citizen of Pera as early as $1411 .{ }^{183}$ A subsequent purchase of a slave is recorded for 1426 from a citizen of Caffa, the Genoese colony on the Black Sea, although the location of the transaction is not clearly indicated. ${ }^{184}$ Another document attests to a stay in Constantinople in 1430 , possibly into $1431 .{ }^{185}$ Lupari's presence in Constantinople is also clearly substantiated by transactions recorded for the years 1438 and 1439 in the Libro dei conti of Giacomo Badoer. ${ }^{186}$

The letter by which Eugenius appointed Lupari to this mission refers to him as citizen of Venice. ${ }^{187}$ In an accompanying safe-conduct, Eugenius calls him a citizen of Bologna. ${ }^{188}$ The archival records resolve this apparent contradiction of his citizenship: Balthasar Lupari's father Venturino was a silk merchant, from a family of silk entrepreneurs who had fled Lucca and settled in Bologna in the

180 As noted above, KolDiTz has traced the financial transactions in great detail, along with key biographical notices of the two financiers, see Ibid, p. 246-256. A fuller biographical picture of Balthasar Lupari, drawing on archival records, is in HALFF, «Did Nicholas of Cusa Talk with Muslims? » of which the following is an abbreviated reflection, citing the primary sources used therein.

181 This is, in fact, one of the few references Cusanus makes throughout his entire work to his mission in Constantinople. Given all the eminent persons he would have met in the city, or on the sea journeys, it is striking that Balthasar Lupari is the only person from that time whom he mentions by name.

182 JASPER Hopkins (ed)., Nicholas of Cusa's De Pace Fidei and Cribratio Alkorani: Translation and Analysis, The Arthur J. Banning Press, Minneapolis 1994, p. 76.

183 Archivio di Stato di Bologna [hereinafter ASBo], Archivio Malvezzi-Lupari, Serie III, Istrumenti e Scritture Lupari, b. 48, no. 43, 18 September 1411.

184 Ibid, b. 49, 10 October 1426.

185 Ibid., b. 50, no. 1, 14 March 1431.

186 BADOER, Libro dei conti, p. 587, 590, 715, 730, 738, 739 and 764.

187 CECCONI, Studi storici, doc. CXLI.

188 Ibid., doc. CXLII. Also in AC, I/2, no. 78. 
early $14^{\text {th }}$ century. ${ }^{189}$ By 1420 at the latest, Balthasar, too, had entered the silk business, ${ }^{190}$ for which Bologna had become a center of production. ${ }^{191}$ And in later years, in the 1440s, he served on a number of occasions as a member of city councils in Bologna. ${ }^{192}$ But there was also a strong and early connection to Venice. In 1430, Balthasar, along with his four brothers, was granted full Venetian citizenship, a status typically given after a lengthy and continuous residence and the payment of taxes. ${ }^{193}$ Balthasar is identified in a notarial act of 1431 as a resident of the Venetian contrada of Sant'Agostino. ${ }^{194}$ In February 1434, the Lupari brothers bought a house in the vicinity of the church of San Giovanni Crisostomo. ${ }^{195}$ Other records from $1434^{196}$ and $1436^{197}$ show the brothers engaged in legal and commercial transactions in Venice.

Answers as to when and how Balthasar Lupari entered Eugenius' circle may lie in as yet unnoticed archival records. The origin of their relationship must have preceded the 1437 mission to Constantinople, as Eugenius, in both his commission and the safe-conduct for Lupari, referred to him as a familiaris - a

189 The chronicler Ghirardacci attributes the rise of the silk production in Bologna to political refugees from Lucca, and refers specifically to a «Luparo Lupari » who came to live in Bologna, see Cherubino GHiRARDACCI, Della Historia di Bologna, Parte Prima, Bologna 1596, p. 574.

190 Two references to Balthasar Lupari for 1420 in ASBo, Miscellanea delle Corporazioni d'Arte, A) Arte della Seta, no. 1, 9 January 1420, and ibid., 3 December 1420.

191 LuCA MolÀ, The Silk Industry of Renaissance Venice, Johns Hopkins University, Baltimore - London 2000, p. 15.

192 Balthasar Lupari was elected to the Council of 120, in 1440: Pompeo Scipione Dolfi, Cronologia delle famiglie nobili di Bologna, presso Gio. Battista Ferroni, Bologna 1670, p. 482. Lupari was also a member of the Anziani, an elected city council of elders, in May and June 1445, January and February 1448, May and June 1452, March and April 1453, and March and April 1455, see ASBo, Comune Governo, Consigli ed ufficiali, Magistrature ed ambascerie, no. 67, c.76, Estrazioni di Anziani, Gonfalonieri del Popolo e Massari delle Arti.

193 The Luparis were granted the fullest citizenship status in the Venetian system, that of cittadini originarii. ASV, Cassiere della bolla Ducale, Grazie, reg. 22, fol. 44r, and ASV, Senato, Privilegi, reg. 2, fol. 33r. These sources identified through the online Cives Veneciarum database of Venetian citizenship privileges established under the supervision of Reinhold Mueller, $<$ http://www.civesveneciarum.net/dettaglio.php?id=1249>, versione 56/2017-02-01, accessed on 23 November 2018.

194 ASBo, Archivio Malvezzi-Lupari, Serie III, Istrumenti e Scritture Lupari, b. 50, no. 1, 14 March 1431.

195 ASV, Cancelleria inferiore, Notai, b. 149 (Vettore Pomino), 1433-1438, fol. 1r. The neighbourhood around S. Giovanni Crisostomo was known as a center of the Lucchese community in Venice. See LuCA MolÀ, La Comunità dei lucchesi a Venezia. Immigrazione e industria della seta nel tardo medioevo, Istituto Veneto di Scienze, Lettere ed Arti, Venezia 1994, p. 221-236.

196 ASV, Cancelleria inferiore, Notai, b. 149 (Vettore Pomino), 1433-1438, fol. 7v, dated 27 July 1434, commission for Balthasar Lupari as agent for Giovanni Soranzo.

197 Ibid., 1433-1438, fol. 33v, dated 26 July 1436, related to a trade partnership involving Francesco Lupari and Antonio Serafino. Gaspare, Balthasar's older brother, even had his testament prepared in Venice, in early 1439. In it, he refers to himself as citizen and resident of Venice, of the confinio of San Giovanni Crisostomo. See ASV, Notarile, Testamenti, b. 824 (notaio Vettore Pomino), nr. 26, 27 February 1438 (more veneto). 
member of his household, just like Michele Zono. ${ }^{198}$ Eugenius may have known the Luparis from his time as papal governor of Bologna in 1423, ${ }^{199}$ or during his two-year residence in Bologna starting in 1436, after his flight from Rome, ${ }^{200}$ or from their work and residence in Venice. ${ }^{201}$ Alternatively, Lupari may have worked with Cristoforo Garatone or Michele Zono, and been commended to Eugenius by Garatone. ${ }^{202}$ As with other persons involved in the 1437 mission, in particular Garatone and Zono, the close relationship to Eugenius continued in the years that followed. In 1445, the Pope made Lupari a comes palatinus, ${ }^{203}$ as he had also done for Zono. Balthasar's older brother Gasparo, too, was given this honorific title for unspecified services and loyalty to the Church. ${ }^{204}$

The Luparis appear to have been successful businessmen, and had invested their earnings in real estate in and around Bologna, ${ }^{205}$ even if there is no indication of extreme wealth, ${ }^{206}$ or of being bankers. Notwithstanding their nonpatrician origin, Balthasar Lupari and others in the family did rise to some political prominence over time. Balthasar, for example, in addition to holding the city offices mentioned earlier, represented the city of Bologna in the conclusion of a strategic alliance between Florence, Venice and Bologna in July $1443 .{ }^{207}$ Moreover, in 1452, he was knighted by Emperor Frederick III during a brief stop of the latter in Bologna, presumably given Balthasar's affiliation with the

198 CECCONI, Studi storici, docs. CXLI and CXLII. Unlike for Zono, a record of his nomination as familiaris of the Pope has not yet been found.

199 On his time as governor of Bologna in 1423, see GiLL, Eugenius IV, p. 33-34.

200 See Hermann Diener, Brigide Schwarz, « Das Itinerar Papst Eugens IV. (1431-1447)», Quellen und Forschungen aus italienischen Archiven und Bibliotheken, 82 (2002), p. 193-230, here p. 216-217 and p. 226. Also: GiLl, Eugenius IV, p. 83. Eugenius was still residing in Bologna when he received Cusanus and the other minority representatives from the Council of Basel in May 1437 and dispatched his delegation to Constantinople, GiLL, Council of Florence, p. 77-78.

201 Perhaps there were trade partnerships between the Condulmer and Lupari families. There are records for example, of joint ventures between a Marco Condulmer - not the legate of the 1437 mission - and merchants of the Luchese community in Venice at the beginning of the $15^{\text {th }}$ century: Molì, La Comunità dei lucchesi, p. 238 and p. 258.

202 Suggested by KoldiTz, Johannes VIII, p. 256.

203 Ibid., p. 256 and fn. 429, citing a register in the Vatican.

204 ASBo, Comune Governo, Feudi e cittadinenza, no. 428, 23 May 1445.

205 As evidenced by a 1449 agreement among the surviving (male) descendants of Venturino on the division of the latter's properties: ASBo, Archivio Malvezzi-Lupari, Serie III, Istrumenti e Scritture Lupari, b. 52, 16 August 1449.

206 The family house in Bologna can still be seen today, at Via dal Luzzo no. 4.

207 Riccardo Predelli (ed.), I libri commemoriali della Republica di Venezia. Regesti, vol. IV, Visentini, Venice 1896, libro XIII, no. 239 and 240, p. 279-280. 
Bentivoglio clan ${ }^{208}$ and as part of the Emperor's agenda of building long-term political support in the Italian city states. ${ }^{209}$

\section{The Pope and the impact of the Council minority representatives}

If the Pope's core team of trusted Venetians covered the diplomatic, financial, logistical, linguistic and military aspects of the mission, what added value did the Council representatives of the minority faction represent for him? The Bishop of Digne, the Bishop of Porto ${ }^{210}$ and Nicholas of Cusa were not selected by Eugenius: they were representatives chosen by the leaders of the minority faction in Basel to present, to the Pope, its decree on the location of a council with the Byzantines, and thereafter to proceed to Constantinople. ${ }^{211}$ After their arrival in Bologna, in May or early June of 1437, Eugenius accepted the minority decree in his bull Salvatoris et Dei Nostri. ${ }^{212}$ He thereupon added the three Council minority ambassadors to his own delegation to Constantinople. In doing so, Eugenius seems to have made a distinction between the two groups of ambassadors, placing his own first. This is clear, for example, from his letter to the Holy Roman Emperor Sigismund, of 7 June 1437, in which Eugenius says that the representatives of the Council and the Greek representatives would proceed, with his own, to Constantinople. ${ }^{213}$ Cusanus, too, underlined the distinction some years later, in his oration at the Diet of Frankfurt, in June 1442. According to the written version of his speech, Cusanus explained that Eugenius « sent envoys to Constantinople, along with those who had presented [the minority] decree to His Holiness $» .{ }^{214}$ In other words, the narrative, as it was adopted at the time by those involved, was that the three ambassadors represented the Council of Basel and not the Pope, and that they were added to the delegation of Eugenius IV.

208 See HalfF, « Did Nicholas of Cusa Talk with Muslims? », p. 40-41.

209 For this observation, I thank Cynthia Pyle. While in Ferrara that year, Frederick III knighted a one-year old child of a prominent family there, Niccolò Postumo da Correggio, a parallel to the knighting of the seven-year old Giovanni son of Annibale Bentivoglio in Bologna at the same time as Lupari, see CYNTHIA M. PYLE, «Politian's Orfeo and Other Favole Mitologiche in the Context of Late Quattrocento Northern Italy », Ph.D. Dissertation, Columbia University, New York 1976.

210 For biographical references of the Bishops of Porto and of Digne, including activities at the Council of Basel, see: Helmrath, Das Basler Konzil, p. 249 (Porto), p. 400 and 435 (Digne); Decaluwé et al., Companion to the Council of Basel, p. 133, 217, 326 and 389 (Digne); GILL, Council of Florence, discusses both Bishops, but not in relation to their careers before the 1437 events.

211 Instructions for the delegation in HALleR, Concilium Basiliense, vol. I, p. 459-463, excerpts in AC I/2, no. 295a.

212 CECCONI, Studi storici, doc. CXXVI. This stage of the events is discussed in GILL, Council of Florence, p. 77-78, and KolDITZ, Johannes VIII, p. 63-64.

213 CECCONI, Studi storici, doc. CXXXI. Also excerpts in AC, I/2, no. 299.

214 IZBICKI, Writings on Church and Reform, p. 179, with emphasis added by me. 
In all the contemporary reports that have been preserved, the three ambassadors continued to be perceived, presented and referred to as representatives of the Council throughout the discussions in Constantinople. In addition to the sources just mentioned, there are the instructions to the fleet commander Antonio Condulmer, in which Eugenius refers to the Bishop of Porto, the Bishop of Digne and Cusanus as the speakers of the Council of Basel, again distinguished from his own. ${ }^{215}$ Similarly, in his letter to Emperor John VIII of 15 July 1437 announcing the arrival of his delegation, Eugenius introduces the three ambassadors by name as representatives of the Council of Basel, along with his own special envoys, Marco Condulmer, and Cristoforo Garatone. ${ }^{216}$ This is also how the former referred to themselves in their own reports. ${ }^{217}$ Furthermore, as the report by the Bishop of Digne presented in Ferrara in March 1438 shows, the papal and conciliar envoys spoke separately on their arrival in September 1437: Garatone for the Pope, and the two Bishops for the Council. ${ }^{218}$

John of Ragusa, who had resided in Constantinople as Council representative since 1435, and who continued to side with the majority faction, felt that he had been deceived by the papal team when they arrived on the Pasqualiga in early September 1437. In his version of the events, Garatone and the Bishops of Digne and Porto withheld information from him about the split in the Council, and presented the minority decree of 7 May 1437 as if it had been the agreed outcome of an undivided Council. ${ }^{219}$ Syropoulos, too, reports the events from this perspective, and suggests that this amounted to a ruse that was exposed as soon as the Council majority convoy arrived. ${ }^{220}$ It is hard to believe, however, that the Byzantines were not already informed of what had happened in Basel. After all, the Emperor's ambassadors to the Council of Basel for 1436-1437, Ioannes Dishypatos $^{221}$ and Manuel Tarchaneiotes Boullotes ${ }^{222}$, had witnessed the ever-

215 Letter to Antonio Condulmer of 6 July 1437, in CECCONI, Studi storici, doc. CXL. Relevant excerpt also in $A C, \mathrm{I} / 2$, no. 312.

216 Letter of Eugenius IV to John VII Paleologos, 15 July 1437, in CECCONI, Studi storici, doc. CXLIX.

217 E.g., the report of the Bishop of Digne, CECCONI, Studi storici, doc. CLXXXVIII: « nos, ambassiatores sacri Concilii ».

218 The Bishop of Digne, describing the ceremony in the Hagia Sophia, in the presence of the Emperor and the Patriarch, the day after their first audience with the Emperor, Ibid., doc. CLXXXVIII.

219 Ibid., doc. CLXXVIII, p. DVII-DVIII.

220 LAURENT, Les 'Mémoires', p. 179.

221 PLP, no. 5537.

222 PLP, no. 3088. For a discussion of the roles of these men - among other members of the Byzantine aristocracy - in the lead-up to the Council, see KoldITZ, Johannes VIII, p. 149-151 and 154-156. 
sharpening divisions in the first months of $1437 .{ }^{223}$ Both had travelled back to Constantinople on the Pasqualiga, ${ }^{224}$ and would presumably have briefed the Emperor on arrival.

In any event, the majority party of the Council, once they did reach Constantinople, understood what was at stake. They had been pushed into a defensive position: they now had to explain why it was they, not the minority representatives who had arrived earlier, who spoke for the Council. In numerous instances in their reports, John of Ragusa and the Bishops of Viseu and Lausanne described the Bishops of Digne and of Porto and Cusanus as false representatives of the Council. ${ }^{225}$ Presenting their own credentials and denying those of the minority faction became the first agenda items for their meeting with the Emperor. ${ }^{226}$ And indeed, in the presence of the Emperor, the two Bishops asserted that only they represented the Council, and that the "false ambassadors", including Cusanus, were to be rejected. ${ }^{227}$ With the presence in Constantinople, however, of a delegation consisting of representatives of both Council and Pope, any possible claim that it was a Church Council, and not the Pope, which represented the universal church and could bind it in reunification discussions, had been neutralized as an argument to persuade the Byzantines (such a conciliarist assertion would, in any event, not have been compatible with Greek ecclesiology, see further below). Eventually the Council representatives perhaps realizing that they were losing ground in this debate, and changing tactics to gain time - proposed as a last-ditch effort that they would remain in Constantinople for six months to protect the city while the Emperor would send

223 Kolditz points out that they were not, however, in Basel at the time of the adoption of the two conflicting decrees by the majority and minority factions on 7 May 1434; see KoLDITZ, Johannes VIII, p. 63-64 and fn. 93.

224 This follows, among others, from an instruction given on 12 August 1437 to the Venetian ambassador to Emperor Sigismund which describes the departure, some days prior, of a galley of the intermediate type, carrying the Pope's envoys and those of the Byzantine Emperor, as well as money for the Cretan crossbowmen, see IORGA, Notes et extraits, II, p. 16. Syropoulos also notes their return to Constantinople with the papal convoy, although he does not specify on which galley, see LAURENT, Les 'Mémoires', p. 173.

225 John of Ragusa's report in CECCONI, Studi storici, doc. CLXXVIII. Similar expression in the report of Viseu and Lausanne, in Ibid., doc. CLXXIX.

226 Haller, Concilium Basiliense, vol. V, p. 260, containing the proposed agenda for the first meeting with the Emperor: 1) present letters of accreditation from the Council; 2) apologize for absence of a third ambassador, who had fallen sick before departure (John, Bishop of Lübeck); 3) present decree denying the legitimacy of the other ambassadors who claim to represent the Council: they are not to be believed.

227 AC, I/2, nr. 328, report of the Bishop of Viseu and the Bishop of Lausanne to the Council of Basel, 3 February 1438. Syropoulos reports that John of Ragusa gave the Patriarch and the Emperor more independent advice, pointing out that it was not in their interest to choose either side, see LAURENT, Les 'Memoires', p. 181. 
an embassy to the Pope and the Council to obtain further clarity. ${ }^{228}$ This offer was turned down, and eventually they were granted no more audiences with either the Emperor or the Patriarch.

What, ultimately, led the Emperor to choose the papal convoy? Was the presence of Nicholas of Cusa and the two Bishops as Council minority representatives relevant in these considerations? Surprisingly, given the detail of his account and his intimate knowledge of the discussions, Syropoulos does not provide a conclusive reading on why, in the end, the Emperor chose to travel with the papal convoy. Syropoulos describes, with a dramatic eye for detail, the standoff between the two Latin delegations after their arrival in Constantinople, ${ }^{229}$ the arguments presented by the Council majority: ${ }^{230}$ the arguments made by the papal delegation, which, in turn, compelled the Council's delegation to prove to the Byzantines how much the money they actually carried, and to defend themselves why they had arrived late to Constantinople, ${ }^{231}$ and the advice given by many Greek prelates to the Emperor that he should not, at present, go anywhere, and that he had good reasons to turn down both offers, since he had agreed to come to an ecumenical council, and this was currently not possible given the divisions between Pope and Council. ${ }^{232}$ The Holy Roman Emperor Sigismund and the Council representative Jean of Ragusa, too, advised the Emperor that it was not in his interest to decide either way. ${ }^{233}$ Even the Ottoman Sultan in Adrianople - for quite different reasons no doubt discouraged him from going to the West. ${ }^{234}$ But after this narrative build-up, Syropoulos announces, without any transition, that the offer of the Council majority was rejected, that their galleys were sent back, and that from that point on preparations were made to sail with the papal galleys. ${ }^{235}$ On what grounds the Emperor cut the knot, Syropoulos does not say.

Other contemporary or near-contemporary Byzantine sources offer little additional insight. The historian Laonikos Chalkokondyles (c. 1423-after 1463) ${ }^{236}$ highlights the division in the Latin church, presenting it as a conflict between the "Germans, who were in the area of the city of Basel» and Pope Eugenius, supported by the Romans, Venetians and other Italians. He notes that each side sent «triremes » to Constantinople, inviting John to a synod hosted by them to

228 Only in version B of the manuscript, LAURENT, Les 'Mémoires', p. 611-613.

229 Ibid., p. 177-179, and 609-611.

230 Ibid., p. 179.

231 Ibid., p. 179-181.

232 Ibid., p. 181. In version B, this advice is also attributed to the court official Adronikos Kantakuzenos (on whom PLP, no. 10957), see Ibid., p. 611-613.

233 Ibid., p. 181 and, for Ragusa, also in version B, p. 613.

234 Ibid., p. 183.

235 Ibid., p. 183.

236 PLP, no. 30512. 
discuss their differences with the Greek church. Chalkokondyles suggests that the choice was purely a matter of timing, and hints at the importance of location: the Emperor « politely dismissed » the ships sent by the Council, stating that he had already committed to the Romans and other Italians, who had « invited him to go there $»{ }^{237}$ The chronicler Doukas (?-after 1462) ${ }^{238}$ does not mention the competing invitations and convoys, but emphasizes the financial aspects of the undertaking and the Pope's promise and proven ability to cover the costs of the journey and the stay of the large Byzantine delegation in Italy. ${ }^{239}$ Neither George Sphrantzes (who, as senior aide to the Emperor's brother Constantine, and present in Constantinople at that very moment, would have been well placed to have insight into the decision-making process), nor the slightly later historian Theodore Spandounes mention any divisions among the Latins. ${ }^{240}$

The question as to why the Emperor chose the papal convoy continues to generate debate in the literature. ${ }^{241}$ The discussion has focused on a number of practical considerations, such as the lateness of the arrival of the Basel convoy, the proposed venue of the council of union and the route there ${ }^{242}$ the superior Greek language skills of the papal delegation (through Garatone), the failure of the Basel majority to bring Cretan crossbowmen as agreed, as well as the more credible assurances that the Pope was able to give about the expenses of the

237 Laonikos ChalkoKondyles, The Histories, trans. by Anthony Kaldellis, Harvard University Press, Cambridge, MA, 2014, 2 vols. (Dumbarton Oaks Medieval Library 33 and 34), here vol. II, p. 9-11.

238 PLP, no. 5685.

239 DouKAS, Decline and Fall of Byzantium to the Ottoman Turks. An Annotated Translation of 'Historia Turco-Byzantina', trans. HARRY J. MAGoulias, Wayne State University Press, Detroit 1975, p. 179: "When the papal triremes had arrived from Italy with the necessary monies to defray their expenses, they boarded and sailed from Constantinople to Venice ».

240 Sphrantzes, Chronicle, p. 49: "We reached the City on September 24. On November 27 of the same year, our emperor Lord John, accompanied by [etc.], departed for the scheduled synod »; SPANDOUNES, Origin of Ottoman Emperors, p. 28, cited above, see fn. 8.

241 See, among other recent contributions, IVAn Mariano, « The Council and Negotiations with the Greeks ", in DeCAluwÉ et al., Companion to the Council of Basel, p. 318-321; Vera ANDRIOPOUlou, "The Logistics of a Union: Diplomatic Communication through the Eyes of Sylvester Syropoulos », in KonDYLI et al., Sylvester Syropoulos, p. 49-67, in particular p. 64-67; ENRICO MoRINI, «L'Union vue par les 'antiunionistes': l'orthodoxie ecclésiologique e l'incohérence de l'orthodoxie de Lyon à Florence », in MARIE-HÉLÈNE BLANCHET, FRÉDÉRIC GABRIEL, Réduire le schisme? Ecclésiologies et politiques de l'union entre orient et occident (XIIIe-XVIIIe siècle), Centre de recherche d'histoire et civilisation de Byzance, Paris 2013 (Monographies, 39), p. 13-40, in particular p. 30-31. Older but still relevant are: PETAR VRANKIć, «Johannes von Ragusa im Ringen um die Teilnahme der Griechen am Basler Konzil », Annuarium historiae conciliorum, 27/28 (1995/96), p. 463-486, in particular p. 484-486; Tuilier, « La mission a Byzanze de Jean de Raguse », p. 137-152. Briefly in GiLL, Council of Florence, p. 81.

242 Nicholas of Cusa too, in his oration at Diet of Frankfurt in 1442, attributes the failure of the Basel delegation to the fact that they insisted on travelling by sea to the port of Aigues Mortes in the Provence, and from there to Basel, a route the Greeks could not be persuaded to take, see IZBICKI, Writings on Church and Reform, p. 179. 
Byzantine delegation. In addition, scholars have highlighted ecclesiological aspects, emphasizing the long-established Byzantine position that unification could only be considered through an ecumenical council. In this analysis, a central consideration for the Greeks would have been whether the papal conception of an ecumenical council, or the conciliar one, came closest to their own ecclesiological ideals. ${ }^{243}$

While a firm answer as to what, ultimately, persuaded the Emperor may be difficult to articulate, the sources do allow us to understand how the Byzantine court responded to the presence of two sets of delegates claiming to represent the Council of Basel. Judging from the accounts of the Council majority, the Byzantines appear to have been frustrated by the dilemma this posed, and to have been greatly unsettled by the infighting among the Latins. Even notices reaching Venice via mercantile channels spoke of the Greek concerns. ${ }^{244}$ The finer points of how canonicallly sound conciliar decisions ought to be made, and the fact that the Bishops of Viseu and Lausanne represented the maior pars of the Council members, may have been irrelevant at the Byzantine court. ${ }^{245}$ Nevertheless, the reports from the Basel representatives provide evidence that, in encounter after encounter with the Byzantine officials, the issue as to who truly spoke for the Council, and how there could be two delegations claiming to do so, arose as major sticking point: in virtually every meeting with the Council majority faction, the Byzantines brought up the discord, ${ }^{246}$ and the Emperor and

243 On Western and Greek notions of « ecumenical council », see KoLDITZ, Johannes VIII, p. 167-187; MoRINI, "L'Union vue par les 'antiunionistes' », in particular p. 24-31; BLANCHET, Georgios Gennadios Scholarios, p. 267-280; GILL, Council of Florence, p. 14-15 and 19. Kolditz cautions against reducing the entire question to a purely ecclesiological one, or indeed assuming that the Byzantine position was a monolithic one, see KolDITZ, Johannes VIII, p. 68-69.

244 A reference to the Byzantine unease with the discord in SANudo, Le vite dei Dogi, p. 146.

245 Syropoulos frames the issue as a division between Council and Pope, and refers to « representatives of the Council» (e.g., LAURENT, Les 'Mémoires', p. 183) in contrast to "the representatives of the Pope » (e.g., Ibid., p.191), by which he also seems to mean the Bishops of Digne and Porto, and sometimes even uses the term "the Bishops of the Pope » (Ibid., p. 179). $\mathrm{He}$ does not distinguish between a minority and a majority faction of the Council. John of Ragusa's more succinct reporting suggests that the notions of maior pars and sanior pars did come up in the discussions, see CECCONI, Studi storici, doc. CLXXVIII, p. dxv.

246 As indicated in the detailed report of the Bishops of Viseu and Lausanne, 3 February 1438, in particular. See HALler, Concilium Basiliense, vol. V, p. 312-335. The discord between Pope and the Council of Basel was raised by the Greeks in discussions with the majority representatives on: 7 October 1437, in a meeting with the Patriarch, p. 317; on 8 October, in a meeting with the Emperor, p. 320; on 9 October, in a meeting with advisers of the Emperor, p. 323; on 11 October, in a meeting with the Emperor, p. 324; on 12 October, in a meeting with the Patriarch, p. 325326; on 15 October, in a meeting with advisers of the Emperor, p. 327-328; and on 17 October, in a meeting with the Emperor, p. 332. No more audiences were granted to the majority representatives after that, except for a final meeting on 30 October. Also briefly noted as an 
the Patriarch made it clear that they were not interested in arbitrating between the factions. ${ }^{247}$

Both the reactions of the Basel majority representatives and those at the Byzantine court, then, show that the arrival of three delegates alongside those of the Pope, claiming to represent the Council of Basel, affected the dynamics in Constantinople in dramatic ways - more so, presumably, than if this had been simply a continuation of Garatone's skilled negotiations on Eugenius's behalf. It was not just that the parallel tracks of diplomacy that had been conducted with the Byzantines on and off since 1433 - one by the Council of Basel, the other by the Pope - had arrived at a final showdown in Constantinople in late 1437: Eugenius had, in effect, commingled the two streams. He did so by continually emphasizing that the three minority envoys were those of the Council, now fully aligned with his approach to a council of union with the Greek Church, while still neatly distinguishing them from his own delegates. It is possible that Eugenius had been mindful of Byzantine interests in doing so: the Greek position that the schism between the Churches could be healed through an ecumenical council only was well known in the West, ${ }^{248}$ and Eugenius would have felt the need to demonstrate that his convoy, and his proposal for the venue of a unification council, had conciliar support. And yet this need not have been a primarily ecclesiological consideration - for either Eugenius or the Byzantines - but rather, or also, a political one: regardless of how the concept of an ecumenical council was defined, John VIII needed certainty that a sustainable agreement was in reach - an agreement with partners who could bind the Latin Church - and for this both the Pope and the Council of Basel were essential.

\section{Conclusions}

The stakes for Eugenius IV in 1437 were very high. Persuading the Byzantines to board the papal galleys, rather than those sent by the Council majority, would be a first step towards a unification of the Churches on his terms, and towards a significant expansion of his authority as Pope over Christians in the East. It would also open the door to a new unified military campaign under papal command in support of Byzantium and against the advancing Ottomans, as eventually launched in 1444. Failure of the 1437 legation would represent - not just to Eugenius, but to all European powers affected by the schism in the Church - a

issue raised by Byzantine interlocutors in John of Ragusa's report, see CECCONI, Studi storici, doc. CLXXVIII, p. dxv.

247 So also KoldiTz, Johannes VIII, p. 66-68.

248 See, among others, GILL, Council of Florence, p. 14-15 and 19, even if what that notion entailed for the Greeks was not always as clearly understood in the West, see KolDITZ, Johannes VIII, p. 167187. 
major victory for the conciliar forces seeking to assert control over papal authority.

Eugenius would have wanted people whom he could trust for this mission. There was already something about Gabriele Condulmer's reliance on a close inner circle that stood out to his contemporaries. Andreas Sylvius Piccolomini, later Pope Pius II, wrote about Eugenius that "on those who enjoyed his confidence he relied somewhat more, and conferred greater power, than was fitting $\gg .{ }^{249}$

Indeed, the biographical findings of this paper cast light on important connections and striking parallels among the members of the papal team, and links to Eugenius himself. This was not a randomly chosen group of men, assembled ad hoc for a job in the East. For all but one of the key agents, the record reveals active connections to, if not service on behalf of, Eugenius that predated 1437 (Marco and Antonio Condulmer; Christoforo Garatone; Alvise Bembo; Michiel Zono; Balthasar Lupari; probably Nicolò Contarini). The single exception (Ettore Pasqualigo) can be linked to others on the mission (by marriage, to a relative of Zono). Almost all members had previous experience in Constantinople or elsewhere in Greece. Aside from the four galley commanders, who could not be anything other than Venetian noblemen, Eugenius's agents were, like himself, non-patricians. Moreover, direct connections among them (particularly Garatone, Zono, Lupari and Pasqualigo) and continued service on behalf of the Pope extended past 1437, in many cases involving continued active roles in Eugenius's eastern policies (Marco and Antonio Condulmer; Garatone; Zono; Bembo; probably Contarini).

With their proven record, including in Constantinople, and with their ties to either Eugenius himself or to Venice, or to both, Marco Condulmer, Cristoforo Garatone, Antonio Condulmer, Alvise Bembo, Michele Zono, Balthasar Lupari, and the other galley commanders were such people in which the Pope could place his full confidence. Eugenius chose most of them himself for the key responsibilities: the nominal leadership, the lead in the actual negotiations, the command of the fleet, and the financing of the undertaking. Together, this thoroughly Venetian group of people represented the brains, the brawn and the "dough " of his mission. None of the Council minority representatives became significantly involved in any of these core functions.

But in addition to loyal, resourceful and well-connected agents, Eugenius needed something else: legitimacy in the eyes of the Byzantines - or what he thought would amount to such legitimacy. Given the deeply divided state of the Roman Church, of which the Byzantines were aware, the Pope needed to show

249 The comment is to be found in: AENEAS Silvius Piccolomini, Europe (c. 1400-1458), trans. Robert BRown, intr. and annot. NANCY BISAHA, The Catholic University of America Press, Washington, DC, 2013, p. 261. 
that he had conciliar weight behind his invitation. After all, the stakes were high for the Byzantines, too: irrespective of matters of ecclesiology, it was risky to make sensitive and unpopular concessions on matters of doctrine and authority in exchange for Western military support, if such an agreement would not bind the Roman Church as a whole.

It is this need for diplomatic and conciliar credibility on the part of Eugenius IV that the three representatives of the Council minority, including Cusanus, could satisfy. Cusanus' value in this company was real, and gave vital conciliar legitimacy to the Pope's delegation, as well as a strategic edge over the Basel representatives. This did not require Cusanus to play an active role in the negotiations, even if his occasional interventions - and we know of one confirmed comment he made involving conciliar history - would have been helpful. As outsiders to Eugenius' trusted, established circle of Venetians, Cusanus and the Bishops of Digne and Porto were probably not expected to handle any of the core functions, and certainly not to take over Garatone's lead in diplomatic matters.

And so one can return to the autobiographical comment with which this paper started, and offer the following new reading: Cusanus - and the Bishops of Digne and Porto - undoubtedly made a difference in the Eugenius IV's efforts to persuade the Byzantines to come to Italy. But that was less because of what he, or they, did or said while in Constantinople. It was all the more so because of what they represented as members of the Council of Basel, and the political weight that this added to the Pope's offer to the Byzantine court. Eugenius IV's decision in May 1437 to add Cusanus and the other two delegates to his mission had a profound impact in Constantinople, possibly exactly how the Pope had intended it: in the eyes of the Byzantines, the Council of Basel - or what remained of it - no longer looked like the reliable, unified partner they needed for an ecumenical assembly. 


\section{Annex 1}

Chronology of movements of persons involved in the mission to Constantinople: May - December $1437^{250}$

7 May In Basel, the Council splits over the location of a council with the Greek church; two opposing decrees are adopted ${ }^{251}$

20 May The Bishop of Digne and Cusanus leave Basel for Bologna to bring news of the minority decree to Eugenius IV $^{252}$

30 May In Bologna, Eugenius IV endorses the minority decree ${ }^{253}$

June/July In Venice, the Senate discusses arrangements for the galleys to be made available to the Pope; ${ }^{254}$ other preparations are also made, including appointing crew members

6 July Eugenius IV gives Antonio Condulmer broad powers for his mission as captain general of the papal convoy to Constantinople ${ }^{255}$

7 July $\quad$ Eugenius tasks Michele Zono and Balthasar Lupari with handling the finances of the mission; ${ }^{256}$ Eugenius issues a safe-conduct for Lupari (and up to eight of his staff). ${ }^{257}$

9 July The Bishops of Digne and Porto, and presumably Garatone, leave Bologna for Venice 258

15 July Eugenius appoints Marco Condulmer, archbishop of Tarentaise, and Garatone as nuncios, ${ }^{259}$ and confers powers of legate de latere on Condulmer ${ }^{260}$

250 This is meant as an aid to the text, not a full discussion of occasional problems of chronology. Not all sources are given when there is more than one. Not covered is the journey from Constantinople back to Venice of the main convoy in late 1437, for which see LAURENT, Les 'Mémoires', p. 196-217 and discussion in TOM MüLlER, «Die Konstantinopelreise der Basler Konzilsminderheit und der Gesandten Papst Eugens IV. (1437/38) », Cusanus Jahrbuch, 7 (2015), p. 3-20.

251 CECCONI, Studi storici, docs. CXX and CXXI.

252 AC, I/2, no. 204, 205.

253 CECCONI, Studi storici, doc. CXXVI,

254 ASV, Senato, Misti, reg. 60, fol. 22v and fol. 23v-24r (4 July), and fol. 30v (6 August). See also SANUDo, Le vite dei Dogi, p. 617, for 7 July 1437.

255 CECCONI, Studi storici, doc. CXL.

256 Ibid., doc. CXLI.

257 Ibid., doc. CXLL.

258 Ibid., doc. CLXXXVIII.

259 Ibid., doc. CXLVII.

260 Ibid., doc. CXLVIII. 
26 July In Venice, Garatone, and the Bishops of Digne and Porto, embark on the intermediate galley (galea bastarda) commanded by Ettore Pasqualigo ${ }^{261}$

c. 1-10 Aug In Venice, Marco Condulmer and Nicholas of Cusa embark on the three great galleys (galee grosse) commanded by Antonio Condulmer ${ }^{262}$

15 August The galea Pasqualiga arrives in Crete. They stay for 4 days, arranging and paying for the hire of 300 crossbowmen, to be transported by the three galleys which will arrive after them ${ }^{263}$

3 September Pasqualigo's galley, with Garatone and the Bishops of Digne and Porto, arrives at Constantinople ${ }^{264}$

7 September The three galleys carrying Marco Condulmer, as well as Cusanus, stop at Karystos, Euboea. Constantine Dragases, brother of John VIII Paleologos (and later Constantine XI Paleologos, last emperor of Byzantium), accompanied by George Sphrantzes, boards ${ }^{265}$

15 September In Constantinople, Emperor John VIII receives Garatone and the Bishops of Digne and Porto

23 September Marco Condulmer, along with Nicholas Cusanus, arrives in Constantinople on the three great galleys ${ }^{266}$

3 October The convoy of the Council of Basel (majority faction) arrives in Constantinople. Numerous meetings take place in October between its ambassadors and the Byzantines ${ }^{267}$

2 November The convoy of the Basel majority leaves Constantinople, emptyhanded ${ }^{268}$

261 Ibid., doc. CLXXXVIII.

262 The exact date has not been established. It would have been shortly after the departure of the Pasqualiga, according to Juan of Segovia, AC, vol. I/2, nr. 319, and is unlikely to have been before $30 \mathrm{July}$, the date of a Senate instruction not to engage in competition with the normal commercial fleet, ASV, Senato, Misti, reg. 60, fol. 28v. Stefano Magno states that the convoy left in August, and that Pasqualigo had left 15 days before them. Since Pasqualigo left on 26 July, this gives an approximate departure of the three galleys including Cusanus on 10 August. That in turn would mean a travel time of 45 days, including stops in Crete and Euboea, compared to 39 days for Pasqualigo (including four days in Crete).

263 CECCONI, Studi storici, doc. CXXXVIII.

264 Ibid., doc CXXXVIII and CLXXVIII.

265 IorGA, Notes et extraits, vol. III, p. 20. In his chronicle, Sphrantzes states that he and Constantine Dragases departed Patras for Karystos by land on 5 September, see SPHRANTZES, Chronicle, p. 49.

266 IORGA, Notes et extraits, vol. III, p. 22 fn.5. Slightly different dates: 22 September according to Magno: ÖNB, Cod. Vind. 6124, fol. 75r; 24 September, according to SPHRANTZES, Chronicle, p. 49.

267 HALLER, Concilium Basiliense, vol. V, p. 310 (arrival), p. 312-336 (negotiations).

268 Ibid., vol. V, p. 342 
18 November John VIII informs Eugenius IV, in a letter entrusted to Michele Zono, that he has decided to come to Italy with the papal galleys 269

19 November Ettore Pasqualigo, captain of the galea bastarda, carrying Michele Zono and members of the Byzantine emperor's household, departs Constantinople for Venice ${ }^{270}$

24 November In Constantinople, the Byzantines and the papal legation gradually board the papal galleys; on 27 November, they depart. ${ }^{271}$ Arrival in Venice early February 1438.

23 December Ettore Pasqualigo arrives in Venice. Michele Zono proceeds immediately to Eugenius in Bologna. ${ }^{272}$

30 December Eugenius announces the imminent arrival of the Byzantine delegates on papal galleys, and reconfirms that the Council has been relocated from Basel to Ferrara ${ }^{273}$

269 Hofmann, « Rodrigo, Dekan von Braga », p. 178.

270 IORGA, Notes et extraits, vol. III, p. 24-25, excerpts from report of the Collegio of Venice to the Cardinal of Sant'Angelo, 21 December 1437. ASV, Collegio, Lettere secrete, reg. 1436-1437, fol. 231v-232r.

271 LAURENT, Les 'Mémoires', p. 197-199; CeCConi, Studi storici, doc. CLXXXVIII.

272 ÖNB, Cod. Vind. 6214, fol. 76r.

273 CECCONI, Studi storici, doc. CLXX. 
Annex 2

Overview of persons affiliated with the papal legation mentioned in the text

Papal nuncios

1. Marco Condulmer, son of Bartholomeo(?). Archbishop of Tarentaise. Nuncio and legate.

2. Cristoforo Garatone, son of Pietro, from Treviso. Bishop of Corone. Nuncio.

Council of Basel minority faction representatives

3. Pierre de Versailles, Bishop of Digne.

4. Antonio Martins de Chaves, Bishop of Porto.

5. Nicholas of Cusa, provost of Münstermaifeld.

\section{Financiers}

6. Michele Zono, son of Nicolò. Merchant. Citizen of Venice.

7. Balthasar Lupari, son of Venturino. Merchant. Citizen of Bologna and Venice.

Galley commanders

8. Antonio Condulmer, son of Bernardo. Capitanio, commander of the convoy, and of the flagship.

9. Ettore Pasqualigo, son of Giovanni. Sopracomito of an intermediate galley.

10. Alvise Bembo, son of Bianco. Sopracomito of a galley.

11. Nicolò Contarini, son of Gasparino (?). Sopracomito of a galley.

Other naval officers

12. Michael of Rhodes, comito on the galley of Alvise Bembo.

13. Nicolò da Candia, paron on the galley of Alvise Bembo

14. Piero Vendilin, homo de conseio on the galley of Alvise Bembo

15. Donà Oxelo, scribe on the galley of Alvise Bembo.

16. Nicolò di Giudecca, comito and/or homo de conseio (?) on the galley of Ettore Pasqualigo. 


\section{Bibliography}

Archival sources

Venice, Archivio di Stato di Venezia

Avogaria di comun, Balla d'Oro, reg. 162-I

Avogaria di comun, Prove di età per patroni di galere e altre cariche, reg. 177-1

Cancelleria inferiore, Notai, b. 149

Cassiere della bolla Ducale, Grazie, reg. 22

Collegio, Notatorio, reg. 6 and 8

Duca di Candia, b.1

Notarile, Testamenti, b. 824 and b. 923

Senato, Mar, reg. 1

Senato, Misti, reg. 60

Senato, Privilegi, reg. 2

Senato, Secreti, reg. 14

Santo Spirito, Pergamene

Bologna, Archivio di Stato di Bologna

Archivio Malvezzi-Lupari

Comune Governo, Consigli ed ufficiali

Comune Governo, Feudi e cittadinenza

Miscellanea delle Corporazioni d'Arte

Vienna, Österreichische Nationalbibliothek

Cod. Vind. 6214

Lat. cod. 6205

\section{Published sources}

Badoer, Giacomo, Il libro dei conti di Giacomo Badoer (Costantinopoli 1436-1440), ed. Umberto Dorini and Tommaso Bertelè, Istituto Poligrafico dello Stato, Rome 1956 (Il nuovo Ramusio, 3).

Cecconi, Eugenio, Studi storici sul Concilio di Firenze. Parte prima: Antecedenti del Concilio, Tipografia all'insegna di S. Antonino, Florence 1869.

Chalkokondyles, Laonikos, The Histories, ed. and trans. Anthony Kaldellis, Harvard University Press, Cambridge, MA - London 2014 (Dumbarton Oaks Medieval Library), 2 vols.

Cicogna, Emmanuele Antonio, Delle inscrizioni Veneziane, vol. II, Giuseppe Picotti, Venice 1827. 
Dolfi, Pompeo Scipione, Cronologia delle famiglie nobili di Bologna con le loro insegne, $e$ nel fine di cimieri, presso Gio. Battista Ferroni, Bologna 1670.

Doukas, Decline and Fall of Byzantium to the Ottoman Turks. An Annotated Translation of 'Historia Turco-Byzantina', trans. Harry J. Magoulias, Wayne State University Press, Detroit 1975.

Fedalto, Giorgio (ed.), Acta Eugenii Papae IV (1431-1447), e Vaticanis aliisque regestis collegit notisque illustravit, Pontificia Commissio Codici Iuris Canonici Orientalis Recognoscendo, Rome 1990.

Ghirardacci, Cherubino, Della Historia di Bologna, vol. I, Bologna 1596.

Haller, Johannes, et al. (eds.), Concilium Basiliense. Studien und Quellen zur Geschichte des Concils von Basel, vol. V: Tagebücher und Acten, Helbling \& Lichtenhahn, Basel 1904.

Haroldus, Franciscus, Beati Alberti a Sarthiano. Opera Omnia, Giovanni Battista Bussotti, Rome 1688

Hofmann, Georgius (ed.), Concilium Florentinum. Documenta et Scriptores, vol. I, part 1, Epistolae Pontificiae ad Concilium Florentinum Spectantes, Pontificium Institutum Orientalium Studiorum, Rome 1940.

Iorga, Nicolai, Notes et Extraits pour servir à l'histoire des croisades au XV siècle, vol. IIII, Ernest Laroux, Paris 1899-1902.

Izbicki, Thomas M. (trans.), Nicholas of Cusa: Writings on Church and Reform, Harvard University Press, Cambridge - London 2008.

Kohl, Benjamin, Andrea Mozzato, Monique O'Connell, The Rulers of Venice, 13321524, www.rulersofvenice.org.

Kugéas, Sokrates (ed.), « Notizbuch eines Beamten der Metropolis in Thessalonike aus dem Anfang des XV. Jahrhunderts », Byzantinische Zeitschrift, 23 (1914/1919), p. 143-163.

Laurent, Vitalien, Les 'Mémoires' du Grand Ecclésiarque de l'Église de Constantinople Sylvestre Syropoulos sur le concile de Florence (1438-1439), Centre National de la Recherche Scientifique, Paris 1971 (Publications de l'Institut français d'études byzantines, 3).

Melville-Jones, John R., Venice and Thessalonica 1423-1430: The Venetian Documents, Unipress, Padua 2002 (Archivio del litorale adriatico, 7).

Meuthen, Erich et al. (eds.), Acta Cusana: Quellen zur Lebensgeschichte des Nikolaus von Kues, Felix Meiner, Hamburg 1976-. 
Mueller, Reinhold C. et al., Cives venetiarum: privilegi di cittadinanza veneziana, dalle origini all'anno 1500, www.civesveneciarum.net.

Nanetti, Andrea (ed.), Il codice Morosini. Il mondo visto da Venezia (1094-1433), 4 vols., Centro Italiano di Studi sull'Alto Medioevo, Spoleto 2010 (Quaderni della Rivista di bizantinistica, 10).

Nicholas of Cusa, Cribratio Alkorani, in Jasper Hopkins (ed.), Nicholas of Cusa's 'De pace fidei' and 'Cribratio Alkorani': Translation and Analysis, The Arthur J. Banning Press, Minneapolis 1994.

Piccolomini, Aeneas Silvius, Europe (c.1400-1458), trans. Robert Brown, intr. and annot. Nancy Bisaha, The Catholic University of America Press, Washington, DC, 2013.

Predelli, Riccardo (ed.), I libri commemoriali della Republica di Venezia. Regesti, vol. IV, Visentini, Venice 1896.

Sanudo il Giovane, Marin, Le vite dei Dogi 1423-1474, ed. Angela Caracciolo Arico and Chiara Frison, vol. I: 1423-1457, La Malcontenta, Venice 1999.

Spandounes, Theodore, On the Origin of the Ottoman Emperors, trans. and ed. Donald M. Nicol, Cambridge University Press, Cambridge, 1977.

Sphrantzes, George, Chronicon maior, in Marios Philippides (ed.), The Fall of the Byzantine Empire: A Chronicle by George Sphrantzes, 1401-1477, University of Massachusetts Press, Amherst 1980.

Tafur, Pero, Travels and Adventures 1435-1439, trans. and ed. Malcolm Letts, Routledge, London 1926 (The Broadway travelers).

Thiriet, Freddy, Régestes des Déliberations du Sénat de Venise concernant la Romanie, Mouton, Paris - The Hague 1961.

- Délibérations des Assemblées Vénitiennes concernant la Romanie, Mouton, Paris The Hague 1971.

Thomas, Georg, Riccardo Predelli, Diplomatarium Veneto-Levantinum, vol. II, Venice 1899.

Studies

Alberigo, Giuseppe (ed.), Christian Unity. The Council of Ferrara-Florence 1438/39-1989, Peeters, Leuven 1991 (Bibliotheca ephemeridum theologicarum Lovaniensium, 97).

Barker, John W., Manuel II Palaeologus (1391-1425): A Study in Late Byzantine Statesmanship, Rutgers University Press, New Brunswick, NJ, 1969. 
Bellitto, Christopher M., Thomas M. Izbicki, Gerald Christianson (eds.), Nicholas of Cusa. A Guide to a Renaissance Man, Paulist Press, New Jersey 2004.

Bertelè, Giacomo (ed.), Il libro dei conti di Giacomo Badoer (Costantinopoli 1436-1440). Complemento e indici, Esedra, Padua 2002 (Numismatica Patavina, 2).

Beverly, Tessa, «Venetian Ambassadors 1454-94: an Italian Elite», Ph.D. Diss. University of Warwick 1999.

Biechler, James E., «Interreligious Dialogue », in Christopher M. Bellitto, Thomas M. Izbicki, Gerald Christianson (eds.), Nicholas of Cusa. A Guide to a Renaissance Man, Paulist Press, New Jersey 2004.

Bilaniuk, Petro, "Nicholas of Cusa and the Council of Florence ", Proceedings of the Patristic, Medieval and Renaissance Conference, 2 (1977), p. 59-75.

Blanchet, Marie-Hélène, Georges-Gennadios Scholarios (vers 1400-vers 1472). Un intellectuel orthodoxe face à la disparition de l'Empire byzantin, Editions l'Institute Français d'Études Byzantines, Paris, 2008, (Archives de l'Orient chrétien, 20).

Blanchet, Marie-Hélène and Thierry Ganchou, «Les fréquentations byzantines de Lodisio de Tabriz, Dominicain de Péra ( $\uparrow 1435)$ : Géôrgios Scholarios, Iôannès Chrysolôras et Théodôros Kalékas ", Byzantion 75 (2005), p. 70-103.

Bond, H. Lawrence, "Nicholas of Cusa from Constantinople to 'Learned Ignorance': The Historical Matrix for the Formation of the De docta ignorantia », in Gerald Christianson, Thomas M. Izbicki (eds.), Nicholas of Cusa on Christ and the Church: Essays in Memory of Chandler McCuskey Brooks for the American Cusanus Society, Brill, Leiden 1996 (Studies in the History of Christian Thought, 71), p. 135163.

Brösch, Marco, Walter Andreas Euler, Alexandra Geissler, Viki Ranff (eds.), Handbuch Nikolaus von Kues. Leben und Werk, Wissenschaftliche Buchgesellschaft, Darmstadt 2014.

Cataldi Palau, Annaclara, « Learning Greek in Fifteenth-Century Constantinople », in Annaclara Cataldi Palau (ed.), Studies in Greek Manuscripts, Fondazione Centro Italiano di Studi sull'Alto Medioevo, Spoleto 2008, p. 219-234.

- «The manuscript production in the Monastery of Prodromos Petra (twelfthfifteenth century) » in Annaclara Cataldi Palau (ed.), Studies in Greek Manuscripts, Fondazione Centro Italiano di Studi sull'Alto Medioevo, Spoleto 2008, p. 235-280.

- «I colleghi di Giorgio Baiophoros: Stefano di Medea, Giorgio Crisococca, Leon Atrapes ", in Annaclara Cataldi Palau (ed.), Studies in Greek Manuscripts, Fondazione Centro Italiano di Studi sull'Alto Medioevo, Spoleto 2008, p. 303-344. 
Christianson, Gerald, Cesarini: The Conciliar Cardinal. The Basel Years, 1431-1438, EOS Verlag, St. Ottilien 1979 (Kirchengeschichtliche Quellen und Studien, 10).

- «Conciliarism and the Council», in Michiel Decaluwé, Thomas M. Izbicki, Gerald Christianson (eds.), A Companion to the Council of Basel, Brill, Leiden 2017 (Brill's Companions to the Christian Tradition, 74), p. 75-111.

Christianson, Gerald, and Thomas M. Izbicki (eds.), Nicholas of Cusa on Christ and the Church: Essays in Memory of Chandler McCuskey Brooks for the American Cusanus Society, Brill, Leiden 1996 (Studies in the History of Christian Thought, 71).

Cicogna, Emmanuele Antonio, Genealogia della nobile famiglia Veneziana Zon pubblicata da Emmanuele A. Cicogna per festeggiare le nozze Marcello-Zon, tip. Giambattista Andreola, Venice 1858.

Cohn, Willy, «Die Basler Konzilsflotte des Jahres 1437 », Basler Zeitschrift für Geschichte und Altertumskunde, 12 (1913), p. 16-52.

Decaluwé, Michiel, A Successful Defeat. Eugene IV's Struggle with the Council of Basel for Ultimate Authority in the Church, 1431-1449, Belgisch Historisch Instituut te Rome/Institut Historique Belge de Rome, Brussels - Rome 2009 (Bibliothèque de l'Institut historique belge de Rome, 59).

Decaluwé, Michiel, Thomas M. Izbicki, Gerald Christianson (eds.), A Companion to the Council of Basel, Brill, Leiden 2017 (Brill's Companions to the Christian Tradition, 74).

Diener, Hermann, Brigide Schwarz, « Das Itinerar Papst Eugens IV. (1431-1447) », Quellen und Forschungen aus italienischen Archiven und Bibliotheken, 82 (2002), p. 193230.

Dieten, J. L. van, « Zu den zwei Fassungen der Memoiren des Silvester Syropoulos über das Konzil von Ferrara-Florenz. Die Umkehrung der These Laurents und die Folgen », Annuarium historiae conciliorum, 11 (1979), p. 367-395.

Doumerc, Bernard, «Les Vénitiens à la Tana au XVe siècle », Le Moyen Âge, 94 (1988), p. 363-379.

Duclow, Donald F., "Life and Works ", in Christopher M. Bellitto, Thomas M. Izbicki, Gerald Christianson (eds.), Nicholas of Cusa. A Guide to a Renaissance Man, Paulist Press, New Jersey 2004.

Eubel, Conradus, Hierarchia Catholica Medii Aevi, vol. II, Sumptibus et Typis Librariae Regensbergianae, Münster 1914.

Euler, Walter Andreas, "Nikolaus von Kues und die Ostkirche: Idee und Wirklichkeit des Religionsdialog », in Andreas Speer, Philipp Steinkrüger (eds.), 
Knotenpunkt Byzanz: Wissensformen und kulturelle Wechselbeziehungen, De Gruyter, Berlin 2012, (Miscellanea Mediaevalia 36), p. 496-509.

Ganchou, Thierry, "Les ultimae voluntates de Manuel et Iôannès Chrysolôras et le séjour de Francesco Filelfo à Constantinople », Byzantinistica, 7 (2005), p. 195-285.

- «Le rachat des Notaras après la chute de Constantinople, ou les relations 'étrangères' de l'élite byzantine au XVe siècle », in Michel Balard and Alain Ducellier (eds.), Migrations et diasporas méditerranéennes (Xe-XVIe siècle): actes du colloque du Conques, octobre 1999, Publications de la Sorbonne, Paris 2002 (Publications de la Sorbonne. Sér. Byzantina Sorbonensia, 19).

- "Giacomo Badoer et Kyr Théodôros Batatzès, 'chomercier di peso' a Constantinople (flor. 1401-1449) », Revue des Études Byzantines, 61 (2003), p. 49-95.

Geanakoplos, Deno John, «The Council of Florence (1438-39) and the Problem of Union between the Byzantine and Latin Churches ", in Id., Constantinople and the West, The University of Wisconsin Press, Madison, WI, 1989 (Gallica, 25), p. 224254.

Gill, Joseph, The Council of Florence, Cambridge University Press, Cambridge 1959.

- Personalities of the Council of Florence and other Essays, Barnes \& Noble, New York 1964.

Guidicini, Giuseppe, Cose notabili della città di Bologna, ossia Storia cronologica de suoi stabili sacri, pubblici e private, Tip. Delle scienze, Bologna 1869.

Halff, Maarten, « Did Nicholas of Cusa Talk with Muslims? Revisiting Cusanus' Sources for the Cribratio Alkorani and Interfaith Dialogue », Revista Española de Filosofía Medieval, 26/1 (2019), p. 29-58.

Helmrath, Johannes, Das Basler Konzil 1431-1439. Forschungsstand und Probleme, Böhlau, Cologne 1987 (Kölner historische Abhandlungen, 32).

Hofmann, Georg, «Päpstliche Gesandschaften für den Nahosten, 1418-1453 », Studia Missionalia, 5 (1949), p. 45-71.

- « Rodrigo, Dekan von Braga; Kaiser Johann VIII. Palaiologos. Zwei Briefe aus Konstantinopel, 13. Oktober und 18. November 1437, zur Vorgeschichte des Konzils von Florenz », Orientalia Christiana Periodica, 9 (1943), p. 171-187.

Imber, Colin, The Crusade of Varna, 1443-45, Ashgate, Aldershot - Burlington, VT, 2006.

Kalous, Antonín, Late Medieval Papal Legation. Between the Councils and the Reformation, Viella, Rome 2017 (Viella History, Art and Humanties Collection, 3). 
Karpov, Serghei, « On the origin of medieval Tana » in $\Sigma \tau \varepsilon \varphi \alpha \mu \circ$, , Studia bizantina ac slavica Vladimíro Vavř́nek dedicata (Byzantinoslavica), 56/1 (1995), p. 227-235.

Kolditz, Sebastian, "The Council of Ferrara-Florence as Reflected in Venetian Chronicles: Preliminary Observations », in Sebastian Kolditz, Markus Koller (eds.), The Byzantine-Ottoman Transition in Venetian Chronicles - La transizione bizantinoottomana nelle chronache veneziane, Viella, Rome 2018 (Venetiana. Centro tedesco di studi veneziani, 19).

- Johannes VIII. Palaiologos und das Konzil von Ferrara-Florenz (1438/39), Hiersemann, Stuttgart 2013 (Monographien zur Geschichte des Mittelalters, 60).

Kondyli, Fontini, Vera Andriopoulou, Eirini Panou and Mary B. Cunningham (eds.), Sylvester Syropoulos on Politics and Culture in the Fifteenth-Century Mediterranean, Ashgate, Surrey-Burlington 2014 (Birmingham Byzantine and Ottoman studies, 16).

Krämer, Werner, « Der Beitrag des Nikolaus von Kues zum Unionskonzil mit der Ostkirche », Mitteilungen und Forschungsbeiträge der Cusanus-Gesellschaft, 9 (1970), p. 34-52.

Lane, Frederic C., Venice: A Maritime Republic, Johns Hopkins University Press, Baltimore - London 1973.

- Venetian Ships and Shipbuilders of the Renaissance, John Hopkins University Press, Baltimore - London 1992 (repr.).

- Andrea Barbarigo, Merchant of Venice. 1418-1449, Octagon, New York 1967 (repr.).

Litta, Pompeo, Famiglie celebri di Italia. Condulmero di Venezia, Venice 1864.

Long, Pamela O., David McGee, Alan M. Stahl (eds.), The Book of Michael of Rhodes. A Fifteenth Century Maritime Manuscript, The MIT Press, Cambridge - London 2009.

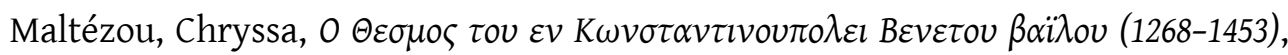
Athens 1970.

Matschke, Klaus-Peter, "Some Merchant Families in Constantinople Before, During and After the Fall of the City 1453 », Balkan Studies, 38/2 (1997), p. 119-238.

Mercati, Giovanni, Scritti d'Isidoro il cardinale Ruteno e codice a lui appartenuti che si conservano nella Biblioteca Apostolica Vaticana, Biblioteca Apostolica Vaticana, Rome 1926 (Studi e testi, 46).

Meserve, Margaret, "Italian Humanists and the Problem of the Crusade ", in Norman Housley (ed.), Crusading in the Fifteenth Century. Message and Impact, Palgrave Macmillan, Hampshire - New York 2004 (Crusades. Subsidia, 8), p. 13-38. 
Meuthen, Erich, Nicholas of Cusa: A Sketch for a Biography, trans and intro. by David Crowner and Gerald Christianson, Catholic University of America Press, Washington, DC, 2010.

Molà, Luca, La Comunità dei lucchesi a Venezia. Immigrazione e industria della seta nel tardo medioevo, Istituto Veneto di Scienze, Lettere ed Arti, Venezia 1994.

- The Silk Industry of Renaissance Venice, Johns Hopkins University, Baltimore, MD, 2000.

Monfasani, John, "Cardinal Bessarion's Greek and Latin Sources in the PlatoAristotle Controversy of the 15th Century and Nicholas of Cusa's Relation to the Controversy ", in Andreas Speer, Philipp Steinkrüger (eds.), Knotenpunkt Byzanz: Wissensformen und kulturelle Wechselbeziehungen, De Gruyter, Berlin 2012, (Miscellanea Mediaevalia 36), p. 469-480.

- « Nicholas of Cusa, the Byzantines and the Greek Language » in Martin Thurner (ed.), Nicolaus Cusanus zwischen Deutschland und Italien, Akademie Verlag, Berlin 2002 (Veröffentlichungen des Grabmann-Institutes zur Erforschung der mittelalterlichen Theologie und Philosophie. Neue Folge, 48).

- George of Trebizond. A Biography and a Study of his Rhetoric and Logic, Brill, Leiden 1976 (Columbia Studies in the Classical Tradition, 1).

Morini, Enrico, «L'Union vue par les 'antiunionistes': l'orthodoxie ecclésiologique e l'incohérence de l'orthodoxie de Lyon à Florence ", in Marie-Hélène Blanchet, Frédéric Gabriel, Réduire le schisme? Ecclésiologies et politiques de l'union entre orient et occident (XIIIe-XVIIIe siècle), Centre de recherche d'histoire et civilisation de Byzance, Paris 2013 (Monographies, 39), p. 13-40.

Moro, Giacomo, "Garatone, Cristoforo », in Dizionario Biografico degli Italiani, vol. 52, Rome 1999, p. 234-238.

Mueller, Reinhold C., «Sull'establishment bancario veneziano. Il banchiere davanti a Dio (secoli XIV-XV) », in Giorgio Borelli (ed.), Mercanti e vita economica nella Repubblica Veneta (secoli XIII-XVIII), vol. I, Banca Popolare di Verona, Verona 1985.

- The Venetian Money Market. Banks, Panics, and the Public Debt, 1200-1500, Johns Hopkins University Press, Baltimore - London 1997.

Müller, Tom, «Die Konstantinopelreise der Basler Konzilsminderheit und der Gesandten Papst Eugens IV. (1437/38) », Cusanus Jahrbuch, 7 (2015), p. 3-20.

Necipoğlu, Nevra, Byzantium between the Ottomans and the Latins. Politics and Society in the Late Empire, Cambridge University Press, Cambridge 2009. 
Nicol, Donald M., Byzantium and Venice. A Study in Diplomatic and Cultural Relations, Cambridge University Press, Cambridge 1988.

- The Last Centuries of Byzantium, 1261-1453, Cambridge University Press, Cambridge 1993 ( $2^{\text {nd }}$ edition).

Oikonomides, Nicolas, Hommes d'affaires grecs et latins à Constantinople (XIIIe-XVe siècles), Institut d'études médiévales Albert-le-Grand-J. Vrin, Montreal-Paris, 1979 (Conférence Albert le Grand, 1977).

Olivieri, Achille, «Condulmer, Marco », in Dizionario Biografico degli Italiani, vol. 27 (1982).

— «Condulmer, Francesco », in Dizionario Biografico degli Italiani, vol. 27 (1982).

O'Rourke Boyle, Marjorie, "Cusanus at Sea: The Topicality of Illuminative Discourse », The Journal of Religion (1991), p. 180-201.

Pesce, Luigi, «Cristoforo Garatone trevigiano, nunzio di Eugenio IV », Rivista di storia della Chiesa in Italia, 28 (1974), p. 23-93.

Philippides, Marios, Walter K. Hanak, Cardinal Isidore, c. 1390-1462. A Late Byzantine Scholar, Warlord and Prelate, Routledge, London - New York, 2018.

Pyle, Cynthia M., «Politian's Orfeo and Other Favole mitologiche in the Context of Late Quattrocento Northern Italy », Ph.D. Diss. Columbia University, New York 1976.

Schreiner, Peter, « Venezianer und Genuesen während der ersten Hälfte des 15. Jahrhunderts in Konstantinopel (1432-1434) », Studi Veneziani, 12 (1970), p. 357368.

Senger, Hans Gerhard, "'In mari me ex Graecia redeunte, credo superno dono'. Vom Wissensfrust zur gelehrten Unwissenheit. Wie platzte 1437/1438 der Knoten? ", in Andreas Speer, Philipp Steinkrüger (eds.), Knotenpunkt Byzanz: Wissensformen und kulturelle Wechselbeziehungen, De Gruyter, Berlin 2012, (Miscellanea Mediaevalia 36), p. 481-495.

Setton, Kenneth M., The Papacy and the Levant (1204-1571), vol. II, The Fifteenth Century, The American Philosophical Society, Philadelphia 1978.

Sopracasa, Alessio, Costantinopoli e il Levante negli atti del notaio veneziano Giacomo dalla Torre (1414-1416), Istituto Veneto di Scienze, Lettere ed Arti, Venice 2015.

Stieber, Joachim W., Pope Eugenius IV, the Council of Basel and the Secular and Ecclesiastical Authorities in the Empire. The Conflict over Supreme Authority and Power in the Church, Brill, Leiden 1978 (Studies in the History of Christian Thought, 13). 
Stöckly, Doris, Le système de l'Incanto des galées du marché a Venise (fin XIIIe - milieu XVe siècle), Brill, Leiden 1995 (The Medieval Mediterranean, 5).

Thiriet, Freddy, La Romanie Vénitienne au Moyen Age, E. De Boccard, Paris 1959 (Bibliothèque des écoles françaises d'Athènes et de Rome, 193).

Tomè, Paola, «Cultura greca e Occidente latino: il caso di Treviso » in Antonio Lovato, Dilva Princivalli (eds.), Mondo latino e civiltà bizantina. Musica, arte e cultura nei codici del '400, CLEUP, Padova 2014 (Fonti e studi per la storia della musica veneta, 4).

Trapp, Erich, et al. (eds.), Prosopographisches Lexikon der Palaiologenzeit, vols. 1-12, Verlag der Österreichischen Akademie der Wissenschaften, Vienna 1976-1996.

Tuilier, André, « La mission a Byzanze de Jean de Raguse, docteur de Sorbonne, et le rôle des Grecs dans la solution de la crise conciliaire », in Bulletin philologique et historique, 1979, p. 137-152.

Vansteenberghe, Edmond, Le Cardinal Nicolas de Cues (1401-1464): L'action - La pensée, Champion, Paris 1920 (Bibliothèque du XV siècle, 24).

Vrankić, Petar, «Johannes von Ragusa im Ringen um die Teilnahme der Griechen am Basler Konzil », Annuarium historiae conciliorum, 27/28 (1995/96), p. 463-486,

Watanabe, Morimichi, "Political and Legal Ideas ", in Christopher M. Bellitto, Thomas M. Izbicki, Gerald Christianson (eds.), Nicholas of Cusa. A Guide to a Renaissance Man, Paulist Press, New Jersey 2004, p. 141-165.

- Nicholas of Cusa. A Companion to his Life and his Times, ed. Gerald Christianson and Thomas M. Izbicki, Ashgate, Farnham - Burlington 2011.

Watts, Pauline M., « Renaissance Humanism », in Christopher M. Bellitto, Thomas M. Izbicki, Gerald Christianson (eds.), Nicholas of Cusa. A Guide to a Renaissance Man, Paulist Press, New Jersey 2004.

Whelan, Mark, «Dances, Dragons and a Pagan Queen: Sigismund of Luxemburg and the Publicizing of the Ottoman Turkish Threat ", in Norman Housley (ed.), The Crusade in the Fifteenth Century. Converging and Competing Cultures, Routledge, Abingdon - London, 2017 (Crusades. Subsidia, 8), p. 49-63.

Zachariadou, Elizabeth E., "The Ottomans, the Greek Orthodox Church and the Perils of the Papacy ", in Kondyli, Fontini, Vera Andriopoulou, Eirini Panou and Mary B. Cunningham (eds.), Sylvester Syropoulos on Politics and Culture in the Fifteenth-Century Mediterranean, Ashgate, Surrey-Burlington 2014 (Birmingham Byzantine and Ottoman studies, 16), p. 23-32. 